Portland State University

PDXScholar

7-12-1991

\title{
The Effect of Urbanization and Modernization on Family Structure in Oman
}

Sultan M. Al-Hashmi

Portland State University

Follow this and additional works at: https://pdxscholar.library.pdx.edu/open_access_etds

Part of the Family, Life Course, and Society Commons, and the Near and Middle Eastern Studies Commons

Let us know how access to this document benefits you.

\section{Recommended Citation}

Al-Hashmi, Sultan M., "The Effect of Urbanization and Modernization on Family Structure in Oman" (1991). Dissertations and Theses. Paper 4123.

https://doi.org/10.15760/etd.6007

This Thesis is brought to you for free and open access. It has been accepted for inclusion in Dissertations and Theses by an authorized administrator of PDXScholar. Please contact us if we can make this document more accessible: pdxscholar@pdx.edu. 
AN ABSTRACT OF THE THESIS OF Sultan M. Al-Hashmi for the Master of Arts in Sociology presented July 12, 1991.

Title: The Effect of Urbanization and Modernization on Family Structure in Oman.

APPROVED BY THE MEMBERS OF THE THESIS COMMITTEE:

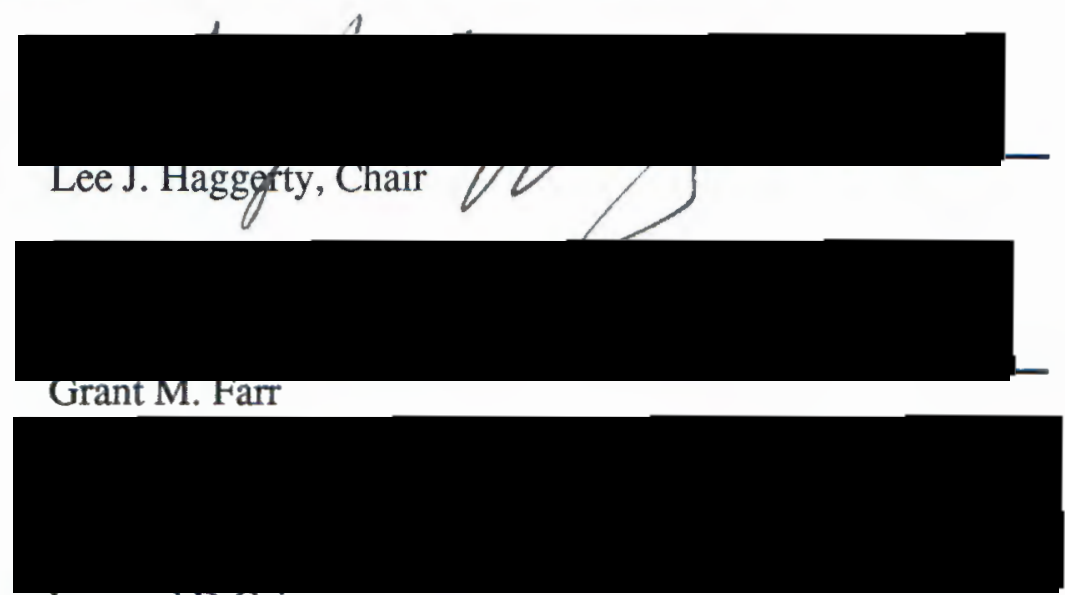

Leonard D Cain

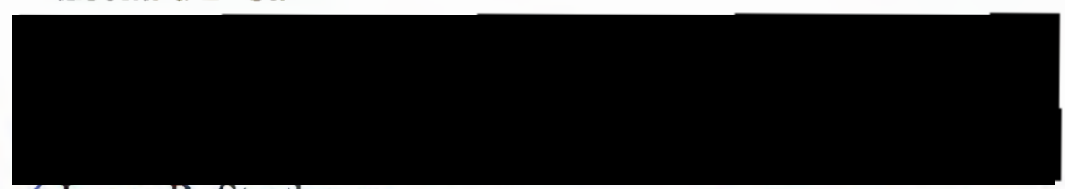

James R. Strathman

This thesis was designed to describe family change in Oman as it undergoes urbanization and modernization. A survey questionnaire to measure these changes was developed. Some questions were developed in two forms for a comparison of family change across two generations. Respondents were asked to answer the questions as they applied to their current family situation. They were then asked to consider, according to their best recollections, what the situation was in their parents' generation.

The major areas of concern were to determine the extent of family structural change and to what degree extended family, modified extended, and nuclear family systems exist 
in Oman today compared with the parental generation. Other areas examined were participation in and strength of the family as well as how child and elderly care are dealt with in the modern citiy of Muscat.

The survey questionnaire was distributed to three hundred government employees working in Muscat, the capital city of the Sultanate of Oman. There were 215 responses received and used in the final analysis. Results suggest only a slight change in the presence of extended family structure between the parental and present generation from $51.2 \%$ to $42.8 \%$ respectively. The study also indicates that about twice as many current families in the capital are nuclear families compared to their parents' generation. On the other hand, twice as many families outside the capital city are extended families compared to families in Muscat. There is also a strong family participation among family members both in and outside the capital area. Finally, the study showed that both child and elderly care are largely a family matter. The oldest son and daughter are expected to provide financial and housing assistance for their parents. Grandparents are preferred for child care help.

Modernization theory suggests that rapid urban and modernization, such as Oman has experienced in the past twenty years, would result in a nuclear family form supplanting traditional extended families. Although extended families are less frequent in the present generation, modern communication and transportation technology has enhanced close family relations among kin, such that the modified extend form of the nuclear family is now more common than the Western nuclear form. The isolated nuclear family, which modernization theory suggests will emerge, is actually less common in Oman now than in the previous generation. 


\title{
THE EFFECT OF URBANIZATION AND MODERNIZATION ON FAMILY STRUCTURE IN OMAN
}

$$
\text { by }
$$

SULTAN M. AL-HASHMI

\begin{abstract}
A thesis submitted in partial fulfillment of the requirements for the degree of
\end{abstract}

\author{
MASTER OF ARTS \\ in \\ SOCIOLOGY
}

Portland State University

1991 
TO THE OFFICE OF GRADUATE STUDIES:

The members of the Committee approve the thesis of Sultan M. Al-Hashmi presented July 12, 1991.
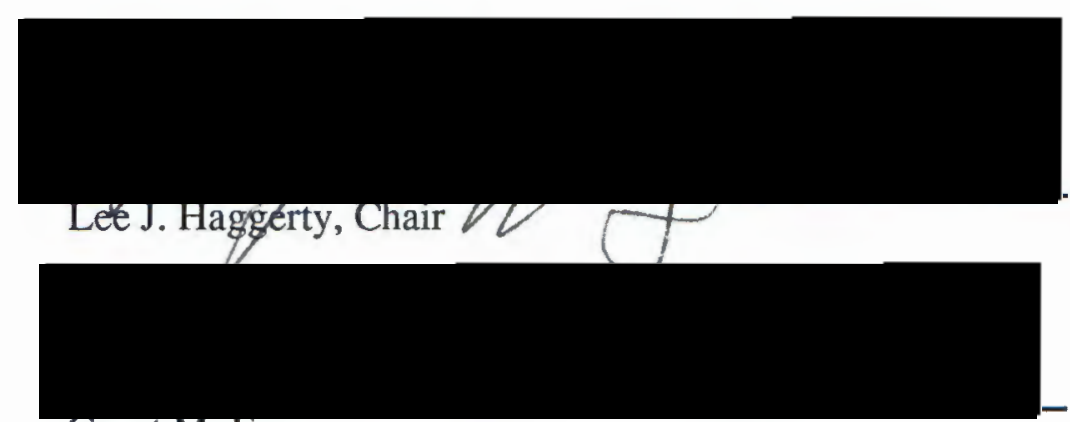

Grant M. Fant
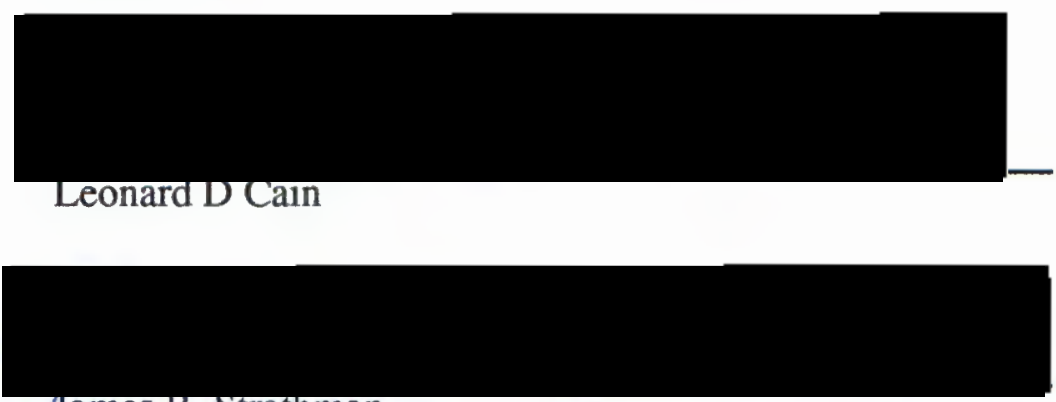

pames R. Strathman

APPROVED:

Grant M. Farr, Chair, Department of Sociology

c. wintam Savery, vice Provost for Graduate studies and Research 


\section{ACKNOWLEDGEMENTS}

First, I would like to thank the Sultan Qaboos University for providing me with a scholarship to continue my education. Second, I would like to express my thank and deep appreciation to my committee members. Dr. Haggerty for his help from the beginning to the end of this thesis. His computer expertise is especially appreciated. Dr. Farr for his expertise in the Middle East and for his help, despite his busy schedule as chair of the Sociology Department. Dr. Cain for his critical analysis. His inspiration beyond numbers made me aware of many facts. I also thank Dr. Strathman, the graduate office representative. His comments were very valuable. Third, my thanks and appreciation go to all men and women who participated in answering the survey questionnaire. Without their time and effort, this research would not have been possible. I am greatly in debt to everyone of them. I also thank very much Wayne McFetridge for putting this thesis in the final form and for his patience with my handwriting. Love and appreciation also go to my family and friends both in Portland, Oregon and Oman. Mr. and Mrs. Whitney for their encouragement and hospitality while my family was in the United States. My brothers Said, Khamis, Raished, and Salem gave me all the support I needed while I was doing the survey (they were real modified extended family members). A special thanks go to my mother and step father for their continuing love and support. Finally, my love and thanks go to my nuclear family; my wife Laura and our children Nasra, Faris, and Raya. Thank you all for being so patient during the rough times. 


\section{CHAPTER}

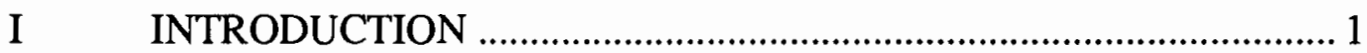

Housing and Land Development in Oman .................................... 2

Social Housing ............................................................................... 4

Oman Housing Bank ................................................................. 5

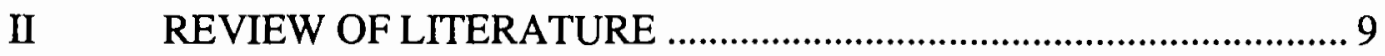

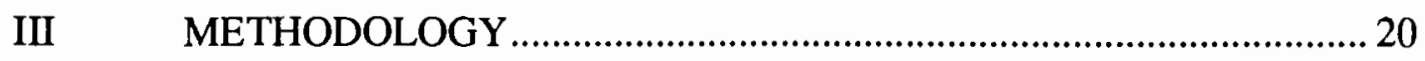

Description of the Survey and Setting …...................................... 20

Limitations and Problems …………......................................... 22

Method of Entering Data................................................................. 23

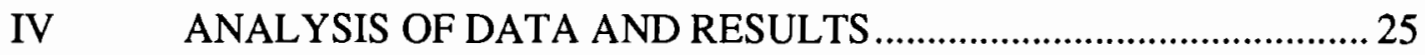

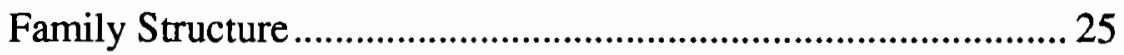

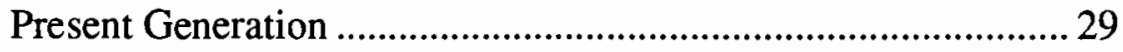

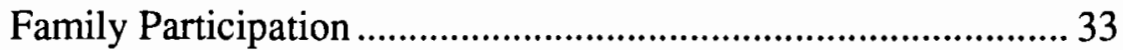

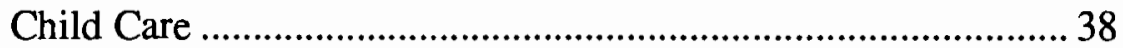

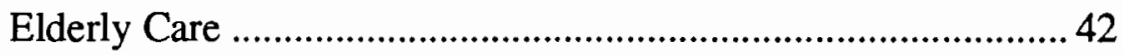


REFERENCES

APPENDIX

A SURVEY QUESTIONNAIRE (ENGLISH VERSION) 55

B SURVEY QUESTIONNAIRE (ARABIC VERSION) 66 


\section{LIST OF TABLES}

TABLE

PAGE

I Housing Development Relative to Total Investment in Million

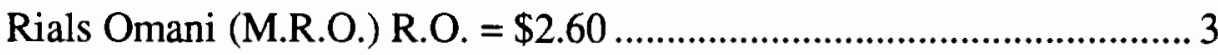

II Total Government Provided Social Houses by Location .......................5

III Distribution of 1989 Loans Compared with 1988 Loans ....................... 6

IV Distribution of Housing Bank Loans up to 1989 by Location ............... 7

V Participant Ministries and Number of Survey Questionnaires

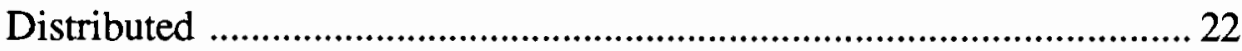

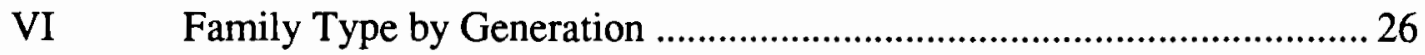

VII Cumulative Percent Living at Given Distances from Relatives, by

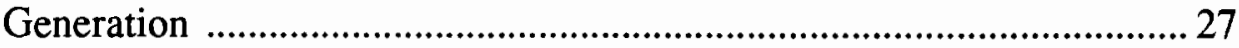

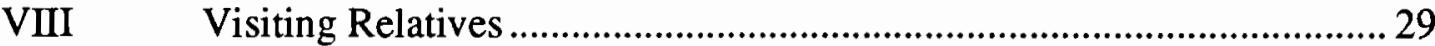

IX Family Type by Living Area (Present Generation) …............................30

$\mathrm{X} \quad$ Family Type by Born and Raised Area (Present Generation) ................. 30

XI Family Type by Type of Housing (Present Generation) .......................... 31

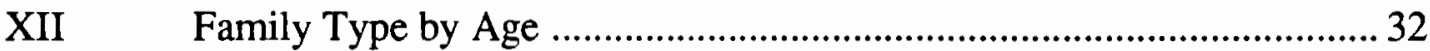

XIII Family Type by Father's Level of Education ....................................... 32

XIV Reason For Living In This Area …….................................................. 33

XV If You Were Given Land or Housing Closer to Your Relatives, Do

You Think it Would Help to Strengthen Family Relations? ?................... 34

XVI Kind and Total Percentage of Help Provided In The Last Year ............. 35

XVII Percentage of Hours Spent In Activities The Last Two Weeks............... 38 
XVIII Average Hours of Childcare Received Last Week from:

XIX Preference of Childcare Source $(1=$ Highest, $6=$ Lowest $)$

XX Distribution of Family Monthly Income and Family Preference In Having Foreign Housekeepers (Child Care)

XXI Housekeeper by Wife Working Survey Result

XXII Foreign Housekeeper Effects On Child

XXIII Total Percentage of Family Having Elderly Who Cannot Care For Him/Herself

XXIV Kind of Help Most Elderly Need

XXV Who offers Most Help To Elderly In the Family (1 = Most,

8 = Least)

XXVI Attitudes About Who Should Be Responsible For Elderly Care 44

XXVII From Whom Do You Expect Care When You Become Elderly $(1=$ Most, $8=$ Least $)$ 


\section{CHAPTER I}

\section{INTRODUCTION}

This thesis will look at the effects of urbanization and modernization on family structure in Muscat, the capital of the Sultanate of Oman. Both urbanization and modernization have stimulated changes in Oman's family structures and functions (Edwards, 1969; Meadows, 1974; and Danesh, 1985). It is expected that structural family patterns will show more "modern" forms than will the norms and values of family life. The three major tasks of concern are: 1) to determine the extent of family structural change, whether extended, modified-extended, or nuclear, and factors associated with such change; 2) family size (fertility) and child care patterns, especially with mothers working to meet modern economic needs; and 3) the upcoming question of the elderly; is it still the children's responsibility to provide care, or the government's, or both?

As recently as 20 years ago, Oman was categorized as an undeveloped "Third World" nation. Oman is a newcomer to modernization in terms of both economic and social development. For the last 20 years, Oman has been rated by many as one of the fastest developing nations. One reason is that the new modern government in Oman, led by his majesty Sultan Qaboos bin Said, had to start from traditionally oriented institutions with very limited resources. Since then, the development in economic sectors, especially oil, has made it possible for the Omani government to develop its old towns and capital and to build new modern towns. Infrastructures such as roads, ports (sea and air), modern hospitals, and schools have also had a high priority. The government institutions developed from very limited numbers of buildings and employees. Historians of development in Oman cite the example of how Oman started in 1970 from a few 
kilometers of roads, three schools, and two hospitals. Today there are 772 schools with over 400,000 male and female students, including one university and many other technical schools and colleges, over 47 hospitals, and over $4,000 \mathrm{kn}$ of asphalt roads $(18,000 \mathrm{~km}$ graded $)$ in the nation, which has a total area of 300,000 square $\mathrm{km}$.

The development of the government sector attracted many Omanis from villages and small towns to work in the government departments in the capital city of Muscat. Some of those in-migrants had never been outside of Oman, but others were returning from neighboring Gulf States having had some exposure to city life. Still others were returning migrants from East Africa. These in-migrants today, together with those who had settled previously in Muscat, form a very heterogeneous society.

\section{HOUSING AND LAND DEVELOPMENT IN OMAN}

Perhaps one of the most important factors that effect the family is housing. Housing is not only important for the family in terms of house size, but in location of the house with respect to other relatives and kin.

Since its early modern development beginning around 1970, the government of Oman has been giving close attention to the service sector in general and housing in particular. Therefore, the relative importance of the service sector comes second to the goods producing sector in all the government's social and economic plans. Table I shows the total investment during the years from 1983 to 1989 and the percentage of the relative importance of service and housing sector investment for both government and private sectors.

Although each ministry or department has a housing development program, the most specialized are in the Ministry of Housing and The Oman Housing Bank. Before 1970 many living arrangements, especially outside the capital, were built in a traditional way. Most of the houses in the villages were built with local material because cement 
was not available. There was only one electric power station in Muscat and most of the houses were unhealthy by modern standards. Furthermore, until recently, diseases such as leprosy and malaria were not under control.

\section{TABLE I}

HOUSING DEVELOPMENT RELATIVE TO TOTAL INVESTMENT IN MILLION RIALS OMANI (M.R.O.)

$$
\text { R.O. }=\$ 2.60
$$

\begin{tabular}{|c|c|c|c|c|c|c|c|c|}
\hline & 1983 & 1984 & 1985 & 1986 & 1987 & 1988 & 1989 & TOTAL \\
\hline $\begin{array}{l}\text { Gross Capital } \\
\text { Investment }\end{array}$ & 736.9 & 913.2 & 953.1 & 898.4 & 564.3 & 511.1 & 441.4 & $\begin{array}{l}5018.1 \\
100 \%\end{array}$ \\
\hline $\begin{array}{l}\text { Total \& Percentage } \\
\text { Investment in Service } \\
\text { Sector Relative to Gross } \\
\text { Capital Investment }\end{array}$ & $\begin{array}{l}186.3 \\
25.3 \%\end{array}$ & $\begin{array}{l}232.5 \\
25.5 \%\end{array}$ & $\begin{array}{l}235.6 \\
24.7 \%\end{array}$ & $\begin{array}{l}188.0 \\
20.9 \%\end{array}$ & $\begin{array}{l}128.4 \\
22.8 \%\end{array}$ & $\begin{array}{l}116.3 \\
22.8 \%\end{array}$ & $\begin{array}{l}100.9 \\
22.9 \%\end{array}$ & $\begin{array}{l}1188.0 \\
23.7 \%\end{array}$ \\
\hline $\begin{array}{l}\text { Total \& Percentage } \\
\text { Investment in Housing } \\
\text { Relative to Gross } \\
\text { Capital Investment }\end{array}$ & $\begin{array}{l}85.0 \\
11.5 \%\end{array}$ & $\begin{array}{l}79.5 \\
8.7 \%\end{array}$ & $\begin{array}{l}81.6 \\
8.6 \%\end{array}$ & $\begin{array}{l}70.4 \\
7.8 \%\end{array}$ & $\begin{array}{l}42.0 \\
7.4 \%\end{array}$ & $\begin{array}{l}45.1 \\
8.8 \%\end{array}$ & $\begin{array}{l}45.6 \\
10.3 \%\end{array}$ & $\begin{array}{l}449.2 \\
9.0 \%\end{array}$ \\
\hline $\begin{array}{l}\text { Percent Housing } \\
\text { Investment Relative to } \\
\text { Service Sector } \\
\text { Investment }\end{array}$ & $45.6 \%$ & $34.2 \%$ & $34.6 \%$ & $37.4 \%$ & $32.7 \%$ & $38.8 \%$ & $45.2 \%$ & $37.8 \%$ \\
\hline
\end{tabular}

Source: Central Bank of Oman Annual Reports 1988, 1989.

Since housing is one of the basic necessities for healthy living, it was one of the early concerns of the government. And, since most of the land in Oman is state-owned, the government set up the Ministry of Housing to implement the general policies of land development. Every citizen can apply for a piece of land from the government to build a house for his family.

General policies of the Ministry of Housing are to disregard social class differences between citizens, to implement the land distribution and housing development policies to provide decent land for all citizens and to encourage family ties through 
housing arrangements. Some of these policies are difficult to meet, especially with land limitations. For example, people can not necessarily get land near their extended family because land is usually distributed by a draw system to ensure fairness between people.

\section{SOCIAL HOUSING}

The Ministry of Housing is also in charge of a Social Housing Program set up to help low income families. This policy helps applicants between 21 and 60 years of age who have a total annual income of less than 1,200 R.O. $(\$ 3,120)$. The rate of monthly installments should not exceed 25 R.O. In fact, many families that can not pay back at such a rate are exempt on many occasions. From 1975 to 1985, there were 5,700 houses built and distributed by the ministry. The ministry allocated 21 million R.O. for the third five-year plan (1986 - 1990) for the housing assistance and rehabilitation which is also part of the ministry's projects. Table II shows the distribution of Social Houses by location. This type of housing is usually built on a compound area with several units on one large parcel of land. There are usually facilities such as a mosque, shops, and a clinic. The problem with this kind of housing is that extended families get separated. If, for example, a married son obtained one of these houses, his parents or relatives would not be able to live with him. These houses are usually small and not designed to accommodate a large family, although some rooms can be added. But, because the house itself is built in a compound, the small amount of land area adjacent to houses cannot accommodate extended family activity. Another problem is that such houses are now more disbursed because large parcels of land are becoming difficult to locate nearby. Therefore, owners of such a house will have to live further from relatives or extended families than desired. Again, these houses are distributed on a random basis through drawings. 
TABLE II

TOTAL GOVERNMENT PROVIDED SOCIAL HOUSES BY LOCATION

\begin{tabular}{|c|c|c|c|c|c|}
\hline Location & $\begin{array}{c}\text { One } \\
\text { Bedroom }\end{array}$ & $\begin{array}{c}\text { Two } \\
\text { Bedroom }\end{array}$ & $\begin{array}{c}\text { Three } \\
\text { Bedroom }\end{array}$ & Total Units & $\begin{array}{l}\text { Total Cost } \\
\text { (M.R.O.) }\end{array}$ \\
\hline Capital (Muscat) & - & 2504 & 196 & 2700 & 64.5 \\
\hline Al-Janubin & 280 & 309 & - & 589 & 9.2 \\
\hline Al-Dakhiliah & 二 & 464 & 50 & 514 & 9.6 \\
\hline Al-Shargiah & 784 & 346 & 一 & 1130 & 11.5 \\
\hline Al-Batinah & 60 & 516 & - & 576 & 9.1 \\
\hline Al-Dahinah & 168 & 442 & $=$ & 610 & 7.6 \\
\hline Musandam & 48 & 178 & $=$ & 224 & 2.6 \\
\hline Total & 1340 & 4757 & 246 & 63463 & 114.2 \\
\hline Total Capital & & & & $\begin{array}{l}2700 \\
42.6 \% \\
\end{array}$ & $\begin{array}{l}64.6 \\
56.6 \% \\
\end{array}$ \\
\hline Total Other Regions & & & & $\begin{array}{l}3643 \\
57.4 \%\end{array}$ & $\begin{array}{l}49.5 \\
43.4 \%\end{array}$ \\
\hline
\end{tabular}

Source: Statistical Year Book; Development Council, 1990

\section{OMAN HOUSING BANK}

The Housing Bank, established in 1977, is $60.9 \%$ government stockholders and was established to provide loans to Omani citizens whose income is higher than those in the first category. People in this category usually hold stable jobs either in the government or in the private sector. The main purpose of the Housing Bank is to encourage urban development by providing loans. From 1977 to the end of 1989, the Bank has given 12,870 loans amounting to $181,082,388$ R.O. (Oman Housing Bank Annual Report, p. 12, 1989). About 8,600 loans were given to lower income groups. 
Table III shows the distribution of loans approved in 1989 compared with 1988 as well as the distribution by income category.

TABLE III

DISTRIBUTION OF 1989 LOANS COMPARED WITH 1988 LOANS

\begin{tabular}{||c|c|c|c|c|c|c|c|c||}
\hline & \multicolumn{9}{|c|}{ Loans Approved During 1989 } & \multicolumn{4}{|c||}{ Loans Approved During 1988 } \\
\hline Monthly Income R.O. & Number & $\%$ & Amount RO & $\%$ & Number & $\%$ & Amount RO & $\%$ \\
\hline Up to 200 & 194 & 20.0 & $1,656,600$ & 10.4 & 171 & 18.2 & $1,485,400$ & 9.3 \\
\hline Above 200 to 400 & 479 & 49.5 & $7,312,500$ & 45.7 & 464 & 49.3 & $7,245,200$ & 45.3 \\
\hline Above 400 to 600 & 212 & 21.9 & $4,747,600$ & 29.7 & 215 & 22.9 & $4,652,700$ & 29.0 \\
\hline Above 600 to 800 & 40 & 4.1 & $1,063,700$ & 6.6 & 61 & 6.5 & $1,739,500$ & 10.9 \\
\hline Above 800 to 1000 & 16 & 1.7 & 496,600 & 3.1 & 18 & 1.9 & 561,700 & 3.5 \\
\hline Above 1000 & 27 & 2.8 & 723,000 & 4.5 & 11 & 1.2 & 315,200 & 2.0 \\
\hline TOTAL & 968 & 100 & $16,000,000$ & 100 & 940 & 100 & $16,000,000$ & 100 \\
\hline
\end{tabular}

Rules set up by the Bank are that those who have monthly incomes of 400.00 R.O. or less will have 20 years to repay their loans. Loan recipients who earn above 400 R.O. monthly will have 15 years to repay. All should repay their loans before they reach the age of 60. It is also Bank policy that no loan should exceed 35,000 R.O. and a husband and wife can have a joint loan if they earn separate incomes, no more than this amount. It should also be mentioned that the government pays part of the loan's interest. For example, those who earn less the 500.00 R.O. monthly pay $4 \%$ and the government pays $6 \%$ of the interest. The government's share of interest decreases as the loan's balance becomes lower. Table IV shows the cumulative loans up to 1989 , including main and regional branches. 
Although the housing bank encourages loans to regions outside Muscat in an effort to slow migration to the capital and to help develop other regions, many

TABLE IV

DISTRIBUTION OF HOUSING BANK LOANS UP TO 1989 BY LOCATION

\begin{tabular}{||c|c|c|c|c||}
\hline & \multicolumn{4}{|c|}{ Loans Cumulative Up To 1989 } \\
\hline Location & Total Loans & Percent & $\begin{array}{c}\text { Amount } \\
\text { (M.R.O.) }\end{array}$ & Percent \\
\hline Capital (Main Branch) & 7684 & 59.7 & 111.5 & 61.6 \\
\hline Al-Janubin & 2534 & 19.7 & 35.2 & 19.4 \\
\hline Al-Dakhiliah & 486 & 3.8 & 6.6 & 3.7 \\
\hline Al-Shargiah & 843 & 6.6 & 11.2 & 6.2 \\
\hline Al-Batinah & 1130 & 8.7 & 14.2 & 7.8 \\
\hline Al-Dahinah & 76 & 0.6 & 1.0 & 0.5 \\
\hline Musandam & 117 & 0.9 & 1.4 & 0.8 \\
\hline Total & 12870 & 100.0 & 181.1 & 100.0 \\
\hline Total Capital & 7684 & 59.7 & 111.5 & 61.6 \\
\hline Total Other Regions & 5186 & 40.3 & 69.6 & 38.4 \\
\hline
\end{tabular}

Source: Oman Housing Bank Annual Report, 1989

government employees who settled in Muscat are forced to build their houses in Muscat because of their jobs. Many of them feel the need for a second house in their place of origin because they visit relatives quite often, desire privacy, and thus build less expensive second houses. This problem, however, should diminish because the government is now trying to create more jobs in other regions by opening branches for its 
ministries and departments. To implement such a policy, the Housing Bank is opening branches in every region to provide housing loans. 


\section{CHAPTER II}

\section{REVIEW OF LITERATURE}

The effect of urbanization and modernization on the family in third world countries has been compared to the effect of industrialization on the family in western societies. Such a comparison, however, should be drawn with caution. The widely held belief, for example, that industrialization in western societies led to the spread of nuclear family forms may not be substantiated when examining the effect of urbanization and modernization on family structure in third world countries (Stone, 1975 and Gittins, 1986). Because of the recency of third world urbanization and modernization, whatever effect they may have on family structure will probably be small compared with those of industrialized countries in the West.

While industrialization and technological revolution in the West provided specialized occupations and freedom of the individual from kinship obligations, urbanization in the third world has provided only limited employment opportunities. Furthermore, urbanization and modernization, as well as a limited government service sector, in third world countries have provided a lower degree of individual mobility in comparison to mobility that accompanies industrialization in the more developed countries.

However, that is not to say that there are fewer social and family changes in third world countries. Brian Berry argues that social change and urbanization in the West were gradual and took over a century. Such changes, however, in contemporary third world nations are moving at faster rates and involve larger populations (Berry, 1981). William Goode suggests that: 
"In all parts of the world for the first time in world history all social systems are moving fast or slowly toward some form of the conjugal family system. With industrialization, the traditional family systems, usually extended or joint, are breaking down." (Goode, 1964, p. 108.)

Goode's argument about the breakdown of the extended family to a conjugal or nuclear family system caused by industrialization should be looked at carefully when studying social and family changes in third world countries because they have lower rates of industrialization.

Looking back at the history of family change in western societies, many family researchers as well as other social scientists could not agree on how the family has changed. Most sociologists agree that there are two main types of family systems: the extended family consisting of the parents, their married children or grandparents, and other kin is most prevalent in pre-industrial societies; the second type, which is widely believed to dominate highly developed western societies, is the nuclear family which consists only of the parents and their unmarried children (Gittins, 1986).

Much of the literature suggests that before industrialization, the extended family type was the majority. Such an argument is based on the fact that before the industrial revolution most societies were under an agricultural subsistence economy. People were attached to the land and, therefore, were held by it. For example, "The son's taking over the farm was so that his parents would remain in the home and be provided for until their death." (Gordon, 1972, p. 2.) This meant that the son would, upon marriage, bring his wife to live with his parents until he inherited the land. Gordon, however, argued that if it was the case in early Europe, it was not so in the pre-industrial period in the United States where land was more available. The son therefore did not have to live with his parents and was free to become independent or start his family. In fact, Gordon further argues that "the nuclear family was the prevailing residential unit long before the industrial revolution." (Gordon, 1972, p. 2.) 
The only argument supporting the existence of the extended family in western societies was that the extended family existed during the feudal period and within the wealthy elite. Only they could afford such a family arrangement. A study by John Demos and Philip Greven (Gordon, 1972) argued that the family in England between the sixteenth and seventeenth century was widely characterized by the nuclear system. Research also has shown that in households in English communities between 1650 and 1780 , there was only about 10 percent extended kin (Ruggles, 1987). However, in his demographic and economic analysis, Ruggles argued that his analysis was consistent with the hypothesis that "people had always wanted to live with extended kin, but before the nineteenth century, economic and demographic constraints prevented them from doing so." (Ruggles, 1987, p. 3.) In his study, Ruggles found that between 1750 and the late nineteenth century in both England and America the percent of households with extended families doubled.

Generally in the literature, there is an argument for the existence of the extended family among very rich families who can afford large housing with servants to accommodate three generations or more. The extended family existed as well among poor families who moved from rural areas to the cities and divided up small residential spaces in order to survive the city expenses. As Tienda and Angel pointed out, "The prevalence of extended living arrangements among poor black families (in the U.S.) is an attempt to cope with economic hardship." (Wilson, 1988, p. 249.) This is not to say that the majority of black families, rich or poor, are the extended family type. Martin and Martin used the term "sub-extensions of an extended family" to describe a new family member who moved out of the extended family and established his own household. In this sense Martin does not see such a household as "constituting nuclear families," but as “sub-extensions of an extended family network." (Martin, et al., 1978. p. 8.) Their reason for this is that the newly formed sub-extended family members feel that they need 
the extended family support financially or emotionally or because they feel an obligation to support their previous extended family. Therefore, the ties among many American black families remained strong throughout history.

Clearly, no society is characterized by only one of these two types of family structures. One society could have several family structure arrangements. And one society may be characterized by more of one type than the others depending on its level of development and progress. As Jean-Louis Flandrin put it, "It is highly misleading to assume the existence of only one type of family at a given point in time." (Gittins, 1986.) Lawrence Stone pointed out that at least three types of family structures existed in Western Europe between 1500 and 1800. Stone labeled these types as 1) "open lineage family," up to the sixteenth century, characterized by strong kinship relations and minimum privacy between spouses; 2) the "restricted patriarchal nuclear family," between 1530 and 1640, characterized by increasing relations between the family and the state; and 3) the "closed domesticated nuclear family," from 1640 to the present, characterized by the idea of individualism and home-oriented way of life (Gittins, 1986). Again, these three types of family structures in Europe cannot be seen as only one type existing in a given period, although one may have been dominant.

Industrialization in western societies made higher mobility possible. There was a large population movement from rural (agricultural) to urban (city and town) life. This process was accompanied by the rise of the state and both the idea of capitalism and Protestantism which resulted in a high rate of individualism and weakening of kinship relations.

Weber pointed out that both the Industrial Revolution and the development of railways in England and the United States were the main cause of the redistribution of population. This resulted in a shift from agricultural types of occupations to a high level of industrial and modern economic systems occupations (Berry, 1981). Ferdinand 
Tönnies called this the transition from "Gemeinschaft," the agricultural and traditional society to "Gesellschaft," the modern professional city way of life. Indeed, Tönnies saw this change as change from where the basic unit of organization was the family or kin group to where the "social and economic relationship are based upon contra-cultural obligations among individuals." (Berry, 1981, p. 10.)

This process was also seen by Emile Durkheim as a change from "mechanical solidarity," or as Berry called it, "segmental" society, to "organic solidarity" or "an organized" society type. Both Tönnies and Durkheim agreed that the shift was from a simple basic type of society to one more complex and well-organized, composed of diverse groups. Such an advanced industrialized type of society is characterized by a high division of labor and by less blood relations as well as more impersonal types of relations between individuals (Berry, 1981).

Louis Wirth described the new environment in the modern city as having large population, high diversity, and heterogeneity. In such an environment there would be less dependence among individuals and "contacts would as a result become impersonal, superficial, and transitory." (Berry, 1981, p. 14.)

We can conclude from these historical events that the effect of industrialization on the family in western societies was not so much on the change from extended to modified extended or to nuclear family structure as it was on a shift in the values, attitudes, and habits of the individual in relation to the family. At the same time, industrialization put reduced emphasis on land ownership and it provided economic freedom for both men and women. By taking work away from the home, the husband and wife spent more time outside the home. The family became free from its traditional function although it remained a basic social institution. Functions such as welfare, child socialization, as well as child education and elderly care and religious training were either taken over by the 
state or other institutions. In an industrialized society, the individual's name and status are not simply inherited, but earned by hard work outside the family (Frankel, 1963).

In summary, as Frankel put it, "industrialization is linked with urbanization, which reinforces the tendencies toward the miniaturization of the family and loosening of the bonds within it." (Frankel, 1963, p. 7.) Therefore, the small nuclear family type became increasingly more common as industrialization and urbanization proceeded. City living arrangements were less able to accommodate an extended or large family. High mobility for jobs called for smaller family size. Education and other modern expenses forced the family to be small. Even many cars were designed to fit families with only two or three children. As the young moved away and formed their family in a different area of settlement than their origin, their attachment to their original family diminished. Their face-to-face communication declined as other means such as telephone and postal services developed. Visiting with extended family members became limited to holidays or when family crises such as death or marriage occurred. In fact, such events became a chance to see family members in western and industrialized societies, due to the increasingly busy way of life.

Analysis of family structure in third world countries, regarding whether it is characterized by the traditional extended system or a nuclear system, has been undertaken by scholars from the West. Third world countries, especially such countries located in which is called the Old World, are expected to have a stronger traditional extended family system. Difference between and within these countries can exist according to the degree of cultural variation. Islam, for example, calls for strong family ties. Caring for the elderly, keeping close ties with relatives, and visiting neighbors regularly are expected.

Furthermore, most of the third world countries are newcomers to industrialization and it is not the same type of industrial revolution that was experienced in the West. Third world countries that experience industrialization today have imported technology 
rather than having developed it on their own. Therefore, change in the family system is expected to be less dramatic than it was to the West. Changes caused by modernization and urbanization on such variables as education and family size are predicted to be slow to effect family values and norms. In fact, some studies investigating the response of the extended family to the effect of modernization and urbanization showed that the extended family either adapted to the new environment or underwent some adaptive change toward what Litwak called the "modified extended family." "The modified extended family . . . does not require geographical propinquity, occupational nepotism, or integration and there are no strict authority relations, but equalitarian ones." (Edwards, 1969, p. 85.)

A study done by Obikeze in western Nigeria, for example, pointed out that the change from the traditional family system to the nuclear was not clear except among the social elite. As Obikeze states, "It was only when the bureaucratic elite was isolated and analyzed separately that a change toward nuclearization became discernible." (Obikeze, 1987, p. 27.) However, $67.7 \%$ of the total of 433 living in cities expressed their view that the "extended family system needed some modification to survive the needs of modern Nigeria." (Obikeze, 1987, p. 41.) Obikeze also pointed out in his study that younger people in cities were more in favor of modification of the family system than the older people or those who lived in rural areas. Another study done in Turkey showed that the extended family is not the norm in Turkish society. According to Vergin, "Extended families with three generations living under the same roof are rare." (Vergin, 1985, p. 571). Also, in Vergin's study, Timur shows that about $50 \%$ of village families are the extended family type. This percentage decreases further among the landless and among urban dwellers. The nuclear family being in the majority (about 70\%) in cities does not, however, mean there is a breakdown in family relations. Vergin's study also reported that "it is not unusual for family members - sisters and brothers, cousins, and parents - to occupy separate apartments in the same building." (Vergin, 1985, p. 572.) This is one 
example showing how the extended family has been modified to fit the modern urban environment. In fact, Kagitchibasi's study showed the "Turks still place a positive value on familial interdependence among relatives." (Vergin, 1985, p. 574.)

As for the Arab countries, William Goode's analysis of the Arab societies shows that "the extended family is predominant" and that the nuclear or what Goode calls the “conjugal family' is common among the educated people (Al-Thakeb, 1985, p. 575). AlThakeb, however, using the 1970 census from different Arab nations, reports that in fact extended families are in the minority. In Egypt, for example, he found that about $77.5 \%$ of families were nuclear. The percentage even further increases in some other Arab countries. Al-Thakeb reported that in Bahrain, about $94 \%$ of the households were composed of a single nuclear family. Using sample of 341 households in Kuwait, he also found that extended families were only $22 \%$ while about $59 \%$ were nuclear families. Further, according to Al-Thakeb's study of Kuwait, about $72 \%$ of the respondents preferred a nuclear family to the traditional patrilocal extended family. His analysis of some Arab censuses also showed that although there is increasing popularity of the nuclear or conjugal family system in many of the Arab societies, the average family size remained high. Among seven Arab countries, the average family size was 5; the lowest in Damascus, Syria and 8 or higher - the highest - in Kuwait and urban Iraq. He also found in his study that there are still strong relations between the nuclear family and their kin; "About $80 \%$ of respondents visited their kin daily or weekly and about $43 \%$ had relatives living next door." (Al-Thakeb, 1985, p. 576 - 579.)

It has been assumed by many researchers that economic development and a high level of urbanization result in a decrease in family size and many studies report that fertility usually declines more in urban areas than in rural areas and in developed nations more than in less developed societies. In third world countries, economic development and urbanization are heavily concentrated in the capital cities and the few towns around 
them, leaving the vast majority of population in rural areas underdeveloped. For example, a study by Abdelrahman and Morgan in Sudan reported that about $50 \%$ of the doctors in Sudan, over $80 \%$ of commercial firms and $70 \%$ of the country's industries were located in the capital area and surrounding towns (Abdelrahman, et al., 1987). Another study by Nassirpour in Iran argues that most of the development in third world countries actually falls within a pseudodevelopment system. Economic and social development are highly concentrated and have little effect on the majority of the population. According to Nassirpour, "Societies allocate revenue in ways that restrict the diversification and expansion of the economy." (Nassirpour, 1985, p.786.) It is the case in most third world countries that the more highly educated remain in the major cities and the capitals. Nassirpour also pointed out that many Iranian girls do not finish or go beyond the high school level of education. This means that the average age at marriage remains very low for females. Nassirpour did, however, report in his findings that there is a high correlation between urban residence and having high school education or beyond for females. However, college education, especially of females, remained in the upper strata of the society (Nassirpour, 1985). This was also supported by the study on Sudan. Girls were encouraged to marry early rather than pursue high levels of education. In studying an Islamic society, the religious tradition is embodied in the culture. Visiting neighbors and relatives, for example, is highly encouraged. Prophet Muhammad (Peace Be Upon Him) has said in this regard, "He who eats to his fill while his neighbor goes without food, is not a believer." (Al-Fahim, 1989, p. 114.) Relations among family and relatives are encouraged even further. In this regard Prophet Muhammad also said, "He who breaks off the ties of blood will not enter paradise." (Al-Fahim, 1989, p. 100.) In another tradition to encourage relations between family individuals, Prophet Muhammad is said to have said: 
"He who just returns the visits of his relatives does not completely fulfill the obligations of relationship. But he who ignores the mistakes of his relatives, forgives them, and visits them in order to bind the ties of the relationship when they are broken does fulfill the obligations of relationship." (Al-Fahim, 1989, p. 102.)

For these reasons, religion has kept the influence of many outside forces on family structure in Islamic and Arabic societies at a minimum. It is therefore not unusual for many to view Arabic societies as having undergone very little change for many generations. As Patai states:

"Beginning with the most ancient times from which historical records are extant and down to the present day, the Middle Eastern family has remained the same, has been composed of largely the same personnel, structured along the same lines, fulfilled the same function, and commanded the same loyalty of its members." (Al-Thakeb, 1985, p. 575.)

Such a generalization, however, is derived essentially from ideology and lacks empirical verification. However, changes in family structure in Arab countries should not be expected to be dramatic. Furthermore, the effect of urbanization and modernization, whatever its force, cannot be expected to be the same as that of industrialization's effect on the western family since the beginning of the industrial revolution. Therefore, even with nuclearization of the family as a response to urbanized life in many growing Arab cities, family ties can be expected to retain their traditional strength.

As is the case in many third world countries, in-migration in Arab states from rural to urban areas is still at a high rate. Such families would be expected to exhibit their traditional values and norms due to the recency of their arrival in the city.

The argument is made by Sussman and Roaieis that "Whatever generational obligations exist are limited to the life span of the nuclear family. The few claims parents have on their children are largely gone when they marry." (Sussman, et al., 1982, p. 258.) This might hold in Western society, but one expects it to be less applicable in many third world countries and certainly in Islamic societies. Children are not only expected to be responsible for their elderly relatives especially in the absence of elderly care 
institutions such as those in the West, but it becomes one's duty toward parent, where "faith constitutes the bedrock for the institution of the family." (Khurshid, 1974, p. 15.)

In summary, family change in structure and values, whether due to industrialization, urbanization, or modernization in general, should not be expected to be at the same rate in third world societies as in the West. Third world societies exhibit a lower rate of industrialization, urbanization, and the availability of technology which leads to lower mobility than that experienced in the West. However, this should not be read as that third world modern cities or even rural settlements are dominated by extended family systems or that of isolated nuclear families as described by Parsons in the West. The nuclear or modified extended family might be the norm in many cities whether in the West or in third world societies, yet the literature does not support the myth that only one type of family system exists in any given society and period of time. One system, however, might be dominant over the others. Furthermore, the family in third world countries in general and Middle Eastern Islamic societies in particular is expected to have stronger family ties than that exhibited in the West, due to the higher rate of social and economic development as well as modern communication and transportation systems in the West and the fact that many areas in third world countries are not exposed to modernization at the same rate as are capitals and major cities and towns. 


\section{CHAPTER III}

\section{METHODOLOGY}

\section{DESCRIPTION OF THE SURVEY AND SETTING}

This research was designed to measure the effect of urbanization and modernization on family structure in Oman. A survey questionnaire designed to measure structural and cultural aspects of family life was developed.

Some of the questions were developed in two forms for a comparison of family change across two generations. Respondents were asked to answer the questions as they applied to their current family situation. They were then asked to consider, according to their best recollections, what the situation was in their parents' generation. These responses allowed for a comparison of the past generation to the present for examining structural and cultural changes in family life in Muscat, Oman.

To accomplish this research, 54 questions were designed (in English) and pretested on ten Omani students studying in Portland, Oregon. The questionnaires were then translated into Arabic and administered to government employees in nine government departments in Muscat. A letter of approval to administer the survey was obtained from the Directorate of Higher Education in Muscat. This letter was presented to participants. It briefly described the purpose of the study and introduced the researcher.

Three hundred surveys of 15 pages each were prepared by Sultan Qaboos University Printing. The survey was conducted in the summer of 1990, from 20 July to 1 September, during working days (Saturday through Wednesday) from 7:30 am to 2:30 
pm. It should be mentioned, however, that the survey was conducted with a nonprobability sample of employees in nine government ministries (there are 21 government ministries and many other government agencies and specialized councils). The participants were taken by convenience and cluster method. Attempts were made to obtain participants from each of the nine ministries, but not proportionally. It was also assumed that the 300 participants (74\% of the questionnaires were returned) share similar characteristics (income, sex, level of education and employee grade level) with the rest of the 42,000 government employees working in the capital or outside the capital area.

The survey was given by the researcher personally to any Omani male or female that agreed to participate in the study and happened to be in the office when the survey was distributed. During survey distribution, attempts were made to include all floors of the ministry when the ministry had more than one. The 300 participants were among 22,682 employees working in nine government ministries. The Table V below shows the number of questionnaires distributed and the number returned in each participant ministry as well as the total number and percent employed in each of the nine ministries.

Participants could take the questionnaire home to avoid taking up their work time. Although the survey was a self-administered questionnaire, considerable time was spent explaining how to answer the survey so it was an advantage to instruct groups of 3 or 6 participants in one office. These sessions, it may be added, were considered an educational experience for both the participants and the researcher.

In addition, in many cases where forms were answered incompletely, much time was spent sitting with the participants to review unanswered questions. This also provided an opportunity to speak more with the participants which, unexpectedly, provided valuable insights. 


\section{LIMITATIONS AND PROBLEMS}

Although this survey was an attempt to describe family change in Muscat, the 215 questionnaires that were completed should not be considered a representative sample of

TABLE V

PARTICIPANT MINISTRIES AND NUMBER OF SURVEY QUESTIONNAIRES DISTRIBUTED

\begin{tabular}{|c|c|c|c|c|c|c|}
\hline Ministry & $\begin{array}{c}\text { Total } \\
\text { Employees } \\
\end{array}$ & Percent & $\begin{array}{c}\text { Questionnaires } \\
\text { Delivered }\end{array}$ & Percent & $\begin{array}{c}\text { Questionnaires } \\
\text { Retumed }\end{array}$ & Percent \\
\hline $\begin{array}{l}\text { Education \& Youth } \\
\text { Affairs }\end{array}$ & 8895 & 39.0 & 53 & 18.0 & 45 & 20.0 \\
\hline Health & 6034 & 27.0 & 37 & 12.0 & 26 & 12.0 \\
\hline Communications & 2532 & 11.0 & 35 & 12.0 & 21 & 9.0 \\
\hline Social Affairs & 755 & 3.0 & 25 & 8.0 & 20 & 9.0 \\
\hline Civil Service & 198 & 1.0 & 20 & 7.0 & 15 & 7.0 \\
\hline Housing & 1198 & 5.0 & 27 & 9.0 & 19 & 9.0 \\
\hline $\begin{array}{l}\text { Justice, Awqaf \& } \\
\text { Islamic Affairs }\end{array}$ & 1985 & 9.0 & 19 & 6.0 & 17 & 8.0 \\
\hline Labor & 855 & 4.0 & 48 & 16.0 & 36 & 16.0 \\
\hline $\begin{array}{l}\text { Development } \\
\text { Council }\end{array}$ & 150 & 1 & 36 & 12.0 & 23 & 10.0 \\
\hline TOTAL & 22602 & 100.0 & 300 & 100.0 & 222 & 100.0 \\
\hline
\end{tabular}

Source of government employees numbers is the Ministry of Civil Service report of 1990-91.

the estimated two million Omani population. Nor, should it be accepted to represent the Omani government employees of 42,020 or to represent the 22,602 Omanis that are employed in the nine government ministries where the 300 participants worked. Since many of these ministry's employees work outside the Capital at the ministry branches, these employees could not be included in the study. It should be mentioned that some of 
the participants who work at the main offices in the Capital are living outside the Capital area. Therefore, the study cannot be generalized to all Omani families. Nonetheless, this study should give an indication of how the family in Oman is changing, especially among those most directly exposed to modern bureaucracy and rapid urban growth, government employees working in the capital of Oman.

Another limitation to this study was that some of the participants could not easily recall their parental life situation. Many male Omanis before 1970 immigrated to neighboring countries for employment, returning only periodically to Oman. Some had families and relatives in ZanZibar. Because of this dispersal of family members, they recalled less information about their parental generation.

Another problem was that although the participant's name, the unit and floor where he or she worked was recorded in a separate notebook in order to avoid confusion when collecting the forms, many problems still occurred. For example, employees were absent on the particular day that questionnaires were to be collected. Some employees were on leave or had work in other offices or departments.

Many times it was necessary to wait for an employee who was receiving a guest, especially among employees at the higher levels of government. Other times, it was necessary to reschedule appointments for another day because some of the officials were in meetings. Therefore, it was not unusual to visit the ministry more than five or six times during the course of the survey. This is a problem to be expected in such a survey setting. It is a very time consuming method.

\section{METHOD OF ENTERING DATA}

In order to analyze the data, the Statistical Package for the Social Sciences (SPSSX) software was used. A codebook was developed. Each form of the survey was given a unique identifying number. A coding scheme was developed to transfer the 
survey questionnaire into a numerical system for entry. Each question was given a variable name and responses were assigned a numerical code. A "9" or "99" was assigned if one question was not answered. Once the survey was coded in a numerical system, data were entered into the IBM 4381 computer for analysis. To analyze the data, tables were constructed for comparisons and frequency distributions were generated for description. Percentages and means were computed and compared to describe changes in the family structure between the present and parental generations, between those of urban and rural origins, and between older and younger respondents as well as the participants' thoughts on the issues of child and elderly care. 


\section{CHAPTER IV}

\section{ANALYSIS OF DATA AND RESULTS}

This thesis has been designed to describe family change in Oman as the society undergoes urbanization and modernization. The five major areas of concern are: 1) to determine the extent of family structural change; to what degree the family is extended, modified extended, or nuclear as it exists in Oman today compared with the parental generation; 2) to examine extended family and nuclear family patterns in Muscat as compared to outside the capital area; 3 ) to describe the degree of family participation such as visiting relatives; 4) to see how the family living in urban Muscat deals with child care; and 5) to explore the elderly care issue: what kind of care the elderly need today in urban Muscat and where such care comes from.

To implement the study, questionnaires were developed and administered to 300 (215 entered the final analysis) government employees in Muscat, the capital city of the Sultanate of Oman. Some of the questions were developed in two forms for a comparison of family change across two generations. Respondents were asked to answer the questions as they applied to their current family situation. They were then asked to consider, according to their best recollections, what the situation was in their parents' generation.

\section{FAMILY STRUCTURE}

The existence of the extended family was indicated if the participants were married and living with (his/her) parents, or single living with parents and grandparents, a married sibling, or had a married child living with them. The modified extended family 
is nuclear in nature with strong relations and participation with the immediate family and relatives. The existence of the modified extended family was determined by the amount of visitation or help provided to other members of the family on a weekly or (at least) monthly basis. The nuclear family is defined as married couples with or without children, divorced with children, or widowed with children. There is a lesser degree of involvement with members of the extended family when compared with the modified extended family.

A comparison of family types from the present generation and the parental generation is shown in Table VI. The percentage of extended family types in the present generation is $42.8 \%$ and is slightly lower than that of the parental generation, $51.2 \%$.

Combining modified and nuclear families results in $57.2 \%$ compared with $48.8 \%$ in the parental generation. There is also an indication that in the past, the family seemed to be less mobile than in the present generation. This is indicated by a higher percentage of $31.2 \%$ for modified extended families in the present generation compared with $18.1 \%$ in the parental generation. Although the modified extended family is a nuclear family in terms of household composition, it keeps close relations with parents and other relatives due to the availability of easy transportation.

TABLE VI

FAMILY TYPE BY GENERATION

\begin{tabular}{||c|c|c||}
\hline \multicolumn{1}{|c|}{ Family Type } & \multicolumn{2}{|c|}{ Generation } \\
\hline & Present Generation & Parents' Generation \\
\hline Extended & 42.8 & 51.2 \\
\hline Modified Extended & 31.2 & 18.1 \\
\hline Nuclear & 26.0 & 30.7 \\
\hline $\mathrm{N}=$ & 215 & 215 \\
\hline
\end{tabular}


Today, people use cars and trucks compared to traditional means of transportation such as camels, donkeys, or ships. The large percentage of modified extended families in the present generation seems to support Litwak's interpretation that such family systems keep strong relations with extended families despite geographical distance and breaks in face to face contact. Such relations can be expressed by sending money to extended family members and helping new family members migrate to the city in order to find employment, provide short-term accommodations, and provide other types of assistance.

Table VII shows that families in the present generation are more geographically dispersed. Seventy-seven percent of the present generation live at least within driving distance compared to $93 \%$ of the parental generation. Although the survey population is different for the present (214) and past (203) generations, more people lived with extended family members in the same house (43.7\%) in the parental generation compared to $33.0 \%$ in the present generation. Nearly $60 \%$ of the parental generation lived in the same house or next door compared to only $40 \%$ in the present generation.

TABLE VII

CUMULATIVE PERCENT LIVING AT GIVEN DISTANCES

FROM RELATIVES, BY GENERATION

\begin{tabular}{||l|c|c|c|c||}
\hline \multicolumn{1}{|c|}{ Location } & \multicolumn{4}{|c|}{ Generation } \\
\hline & $\begin{array}{c}\text { Present } \\
\text { Generation }\end{array}$ & $\begin{array}{c}\text { Cumulative } \\
\text { Percent }\end{array}$ & $\begin{array}{c}\text { Parents' } \\
\text { Generation }\end{array}$ & $\begin{array}{c}\text { Cumulative } \\
\text { Percent }\end{array}$ \\
\hline Same House & 33.0 & 33.0 & 43.7 & 43.7 \\
\hline Next Door & 7.3 & 40.3 & 14.0 & 57.7 \\
\hline Walking Distance & 11.9 & 52.2 & 21.9 & 79.6 \\
\hline Driving Distance & 25.1 & 77.3 & 13.4 & 93.0 \\
\hline Far Away & 22.6 & $100 \%$ & 7.0 & $100 \%$ \\
\hline $\mathrm{N}=$ & 214 & & 203 & \\
\hline
\end{tabular}


Table VII also indicates that there were more family members and relatives in the parental generation living within walking distance than today: $79.6 \%$ compared to $52.2 \%$. However, the percentage living far away is much higher in the present generation, $22.6 \%$, than the $7.0 \%$ in the parental generation. Again, this indicates the dispersement of the family as people move from area to area following jobs or better services.

Past generations in Oman lived closer to each other and worked in the same area in traditional agricultural or fishing jobs. Most of the time, such jobs were handed down from one generation to the next within the family. Therefore, moving away was uncommon, unlike today where there are alternative types of employment.

Table VIII shows the mean number of relatives visited in the present generation compared with the parental generation for those living in the capital and outside the capital. Clearly, the mean of 5.9 for both the capital and outside the capital in the parental generation indicates that people living in the capital were similar in their extent of visiting relatives to those who lived outside the capital. There is very little difference in visiting weekly, monthly, and annually between those living inside and outside the capital.

As for the present generation, Table VIII indicates some variation in the mean. Those living outside the capital visited more relatives daily, 6.8, than those living in the capital, 5.7. The mean is also higher for visiting relatives weekly outside the capital, 6.1, compared to 4.3 within the capital area. Overall, the mean of listed relatives in the present generation is much higher than in the parental generation, 20.7 compared to 14.0. This illustration indicates further the dispersement of families in the present generation when compared to the parental generation. Relatives in the past lived closer and saw each other on a daily basis, therefore, they did not have to make visiting trips. Today 
more people have migrated to the city leaving many relatives in the rural areas and visit them during holidays or special occasions such as marriages or deaths in the family.

TABLE VIII

VISITING RELATIVES

\begin{tabular}{||l|c|c|c|c||}
\hline & \multicolumn{2}{|c|}{ Present Generation } & \multicolumn{2}{c|}{ Parents' Generation } \\
\hline & Capital & Out of Capital & Capital & Out of Capital \\
\hline Daily & 5.7 & 6.8 & 5.9 & 5.9 \\
\hline Weekly & 4.3 & 6.1 & 2.0 & 2.5 \\
\hline Monthly & 3.9 & 3.7 & 2.4 & 1.9 \\
\hline $\begin{array}{l}\text { Semi-Annually } \\
\text { Hardly Ever }\end{array}$ & 1.8 & 0.7 & 1.4 & 1.7 \\
\hline $\begin{array}{l}\text { Mean Number of } \\
\text { Relatives Listed }\end{array}$ & 4.8 & 3.8 & 2.4 & 1.8 \\
\hline
\end{tabular}

\section{PRESENT GENERATION}

Table IX shows percentage differences between extended and nuclear families living in the capital and outside the capital area. The data for those living outside the capital were obtained from employees who work in Muscat but live outside the city. There is a much higher percentage of nuclear families in the capital (67.1\%) compared with outside Muscat (38.5\%).

It was hypothesized that those who are exposed to modern living conditions will exhibit more nuclear family values and structures. Table IX clearly supports this. Table $\mathrm{X}$ shows a comparison of extended family types among those born and raised in the capital or outside Oman and those who were originally born and raised in rural Oman. 
There is a higher percentage of modified extended families among those born in the capital when compared with those born outside the capital. This seems to support the

TABLE IX

FAMILY TYPE BY LIVING AREA

(PRESENT GENERATION)

\begin{tabular}{||l|c|c||}
\hline \multicolumn{1}{|c|}{ Family Type } & \multicolumn{2}{|c|}{ Generation } \\
\hline & Capital & Out of Capital \\
\hline Nuclear & $67.1 \%$ & $38.5 \%$ \\
\hline Extended Family & 32.9 & 61.5 \\
\hline $\mathrm{N}=$ & 146 & 65 \\
\hline
\end{tabular}

TABLE X

FAMILY TYPE BY BORN AND RAISED AREA (PRESENT GENERATION)

\begin{tabular}{||c|c|c||}
\hline \multicolumn{1}{|c|}{ Family Type } & $\begin{array}{c}\text { Born \& Raised in Capital or } \\
\text { Outside Oman }\end{array}$ & Born \& Raised in Rural Oman \\
\hline Extended & $43.8 \%$ & $39.5 \%$ \\
\hline Modified Extended & 32.7 & 27.9 \\
\hline Nuclear & 23.5 & 32.6 \\
\hline $\mathrm{N}=$ & 162 & 43 \\
\hline
\end{tabular}

interpretation that strength of culture and family ties is actually enhanced in the modern Middle Eastern city. In fact, this observation, when combined with earlier observation seen in Table VI regarding the existence of a large number of extended families in Oman, seems to support the argument (Al-Thakeb, 1985; Goode, 1968) that Middle Eastern, and Arab societies in particular, exhibit slower rates of family change. This is also an 
indication that extended families have the ability to adapt to meet the forces of urbanization and modernization. Furthermore, economic growth in recent years has led to stabilization of the family since most Arab societies, especially in the Arabian Peninsula, are Bedouin societies that are known for their high mobility in the desert. Table $\mathrm{X}$ also indicates a higher percentage of nuclear families among those born and raised in rural Oman when compared with those born and raised in the city or outside Oman. This suggests that many Omanis immigrated to the city from rural areas. They settled and formed nuclear families away from their extended families and kinships in the rural area.

The relation between types of family and types of housing was examined. It might be expected that extended family living is less common in the city because of the changes in housing type. However, Table XI shows that the extended family can adapt to modern types of housing. The traditional type of housing is more suitable for extended family activity as indicated by the large percentage of extended family living in traditional housing both in and outside the capital. Table XI also shows a clear decrease of traditional types of housing in the capital. Therefore, the extended family would be expected to further adapt to modern types of housing (usually smaller and less flexible in

\section{TABLE XI}

FAMILY TYPE BY TYPE OF HOUSING

(PRESENT GENERATION)

\begin{tabular}{||l|c|c|c|c|c|c||}
\hline \multirow{2}{*}{ Family Type } & \multicolumn{3}{|c|}{ In Capital } & \multicolumn{3}{c||}{ Outside Capital } \\
\cline { 2 - 8 } & Traditional & Modern & Apartment & Traditional & Modern & Apartment \\
\hline Extended & $43.8 \%$ & $33.3 \%$ & $20.0 \%$ & $69.6 \%$ & $59.5 \%$ & $100.0 \%$ \\
\hline Modified Extended & 28.1 & 32.2 & 48.0 & 17.4 & 29.7 & - \\
\hline Nuclear & 28.1 & 34.2 & 32.0 & 13.0 & 10.8 & - \\
\hline $\mathrm{N}=$ & 32 & 87 & 25 & 23 & 37 & 1 \\
\hline
\end{tabular}


terms of size and the ability to add more rooms) or be forced by the effect of urbanization to move more toward a modified extended or nuclear family type.

Family type was also examined by the participants' age and fathers' level of education. Both tables XII and XIII show the effect of modernization on the extended family. Table XII indicates family type by age. It shows that the nuclear family type increases as age increases. Thus, respondents under 24 years of age live in extended families and move to a nuclear type of family as they become independent. This finding was also consistent when family type was examined by the father's level of education.

TABLE XII

FAMILY TYPE BY AGE

\begin{tabular}{||c|c|c|c||}
\hline & Under 24 & $24-29$ & Over 30 \\
\hline Extended & $64.7 \%$ & $32.9 \%$ & $32.4 \%$ \\
\hline Nuclear & 35.3 & 67.1 & 67.5 \\
\hline $\mathrm{N}=$ & 68 & 76 & 68 \\
\hline
\end{tabular}

Table XIII illustrates these results. The percentage of nuclear families is higher and the extended families decrease as the father's level of education increases. This finding is also in support of an earlier cited study in Nigeria "Education and the Extended

TABLE XIII

FAMILY TYPE BY FATHER'S LEVEL OF EDUCATION

\begin{tabular}{||l|c|c|c|c|c|c|}
\hline Family Type & $\begin{array}{c}\text { No } \\
\text { Education }\end{array}$ & $\begin{array}{c}\text { Informal } \\
\text { Education }\end{array}$ & $\begin{array}{c}\text { Elementary } \\
\text { Education }\end{array}$ & $\begin{array}{c}\text { Secondary } \\
\text { Education }\end{array}$ & $\begin{array}{c}\text { College } \\
\text { Education }\end{array}$ & $\begin{array}{c}\text { Advanced } \\
\text { Studies }\end{array}$ \\
\hline Nuclear & $50.0 \%$ & $56.8 \%$ & $66.7 \%$ & $85.7 \%$ & $100.0 \%$ & $66.7 \%$ \\
\hline Extended & 50.0 & 43.2 & 33.3 & 14.3 & - & 33.3 \\
\hline $\mathrm{N}=$ & 82 & 88 & 24 & 7 & 6 & 3 \\
\hline
\end{tabular}


Family Ideology" by Obikeze. Obikeze pointed out that the extended family was less common among the elite, well-educated Nigerian. Younger Nigerians preferred the modified extended over the extended family type. This suggests that as modernization occurs, we might expect further erosion of extended family living arrangements.

\section{FAMILY PARTICIPATION}

The questions in this section were designed to measure family closeness in terms of both distance and strength in family relations. It was assumed that land distribution would have an effect on family closeness. Therefore, participants were asked about the reason for their choice of living location to determine if there was a significant effect of land distribution on their decision. Since most land in Oman is owned, distributed, and regulated by the government, such land, especially for housing, is distributed through a draw system to ensure fairness among people. This might have an effect on family living locations. The results shown in Table XIV indicate that the highest percentage of people $35.6 \%$, live where the do by their own choice. Inheritance of land or homes was indicated by $21.0 \%$ and land distribution was the third most frequent specific reason at $17.8 \%$.

TABLE XIV

REASON FOR LIVING IN THIS AREA

\begin{tabular}{||c|c|c|c|c|c|c|c|}
\hline & $\begin{array}{c}\text { Land } \\
\text { Distribution }\end{array}$ & Inheritance & Affordability & $\begin{array}{c}\text { Own } \\
\text { Choice }\end{array}$ & Other & TOTAL & $\mathbf{N}$ \\
\hline Percent & 17.8 & 21.0 & 5.2 & 35.6 & 20.4 & $100 \%$ & 191 \\
\hline
\end{tabular}

Although the largest percentage of participants live where they do by their own choice, such percentages should be expected to decrease as land becomes further limited, 
especially in the capital. It would be a useful policy in the future to locate eligible members of the same family in one location to strengthen family relations. Table XV shows that when participants were asked whether given land closer to their families would strengthen family relations, a high percentage of $68.4 \%$ 'definitely agreed' and $20.6 \%$ indicated it would 'probably' strengthen ties. Only $3.8 \%$ answered 'probably not' and $6.2 \%$ were uncertain if given land close to relatives would strengthen their relations.

\section{TABLE XV}

IF YOU WERE GIVEN LAND OR HOUSING CLOSER TO YOUR RELATIVES, DO YOU THINK IT WOULD HELP TO STRENGTHEN FAMILY RELATIONS?

\begin{tabular}{|c|c|c|c|c|c|c|c|}
\hline & $\begin{array}{c}\text { Definitely } \\
\text { Agree }\end{array}$ & Probably & Uncertain & $\begin{array}{c}\text { Probably } \\
\text { Not }\end{array}$ & $\begin{array}{c}\text { Definitely } \\
\text { Not }\end{array}$ & TOTAL & N \\
\hline Percent & 68.4 & 20.6 & 6.2 & 3.8 & 1.0 & $100 \%$ & 209 \\
\hline
\end{tabular}

Table XVI illustrates help provided to immediate family members who do not live in the same house, to relatives, friends, and neighbors within the past year. The types of assistance are categorized as financial aid, food and clothing, finding employment, providing short-term accommodations, and marriage advice and helping in solving problems. Table XVI shows that a third of the respondents provide short-term accommodations (overnight visits) and advice on marriage and problems on a weekly basis to immediate family members. A quarter provide financial assistance and food and clothing to family members on a weekly basis as well. Unlike the traditional mechanism of keeping jobs within the family, however, over $60 \%$ said they hardly ever helped immediate family members find employment. With the exception of help with employment then, there is a very high level of help rendered to the immediate family regularly. 
Nearly 1 in 5 provide short-term accommodations and advice to other relatives on a weekly basis as well, but help with financial assistance and food and clothing on a regular basis is far less common than for immediate family members.

The pattern of percentages providing help for these specific things shows closer relationships with immediate family members than with other relatives, friends, and neighbors. Other relatives and friends receive help at about the same levels with neighbors receiving the least frequent help.

It is interesting to note that advice on marriage and problem solving is hardly ever given to immediate family members by over a quarter (28.8\%) of the respondents. Fortyone percent hardly every give such advice to other relatives, nearly half (47.8\%) hardly ever give such advice to friends and a clear majority (57.7\%) refrain from advising neighbors on such matters. The provision of financial assistance and short-term accommodations follows the same pattern. This pattern suggest that primary interaction

TABLE XVI

KIND AND TOTAL PERCENTAGE OF HELP PROVIDED IN THE LAST YEAR

\begin{tabular}{||c|c|c|c|c|c||}
\hline \hline Relations & $\begin{array}{c}\text { Financial } \\
\text { Assistance }\end{array}$ & $\begin{array}{c}\text { Food And } \\
\text { Clothing }\end{array}$ & $\begin{array}{c}\text { Finding } \\
\text { Employment }\end{array}$ & $\begin{array}{c}\text { Short-Term } \\
\text { Accommodation }\end{array}$ & $\begin{array}{c}\text { Marriage Advice/ } \\
\text { Problem Solving }\end{array}$ \\
\hline Immediate Family & & & & & \\
\hline Weekly & $23.8 \%$ & $29.0 \%$ & $12.6 \%$ & $34.7 \%$ & $34.2 \%$ \\
\hline Monthly & 62.8 & 45.8 & 11.8 & 29.2 & 22.6 \\
\hline Annually & 4.7 & 10.3 & 13.4 & 14.6 & 14.4 \\
\hline Hardly Ever & 8.7 & 14.8 & 62.2 & 21.5 & 28.8 \\
\hline $\mathrm{N}=$ & 172 & 155 & 119 & 144 & 146 \\
\hline
\end{tabular}


TABLE XVI

KIND AND TOTAL PERCENTAGE OF HELP PROVIDED

IN THE LAST YEAR

(continued)

\begin{tabular}{|c|c|c|c|c|c|}
\hline Relations & $\begin{array}{l}\text { Financial } \\
\text { Assistance }\end{array}$ & $\begin{array}{l}\text { Food And } \\
\text { Clothing }\end{array}$ & $\begin{array}{c}\text { Finding } \\
\text { Employment }\end{array}$ & $\begin{array}{c}\text { Short-Term } \\
\text { Accommodation }\end{array}$ & $\begin{array}{l}\text { Marriage Advice/ } \\
\text { Problem Solving }\end{array}$ \\
\hline \multicolumn{6}{|l|}{ Other Relatives } \\
\hline Weekly & $3.5 \%$ & $0.8 \%$ & $2.9 \%$ & $18.6 \%$ & $17.8 \%$ \\
\hline Monthly & 16.8 & 15.6 & 7.7 & 35.7 & 20.0 \\
\hline Annually & 44.8 & 27.0 & 22.1 & 19.3 & 21.5 \\
\hline Hardly Ever & 35.0 & 56.6 & 67.3 & 26.4 & 40.7 \\
\hline$N=$ & 143 & 122 & 104 & 140 & 135 \\
\hline \multicolumn{6}{|l|}{ Friends } \\
\hline Weekly & $5.8 \%$ & $1.8 \%$ & $3.3 \%$ & $18.4 \%$ & $14.5 \%$ \\
\hline Monthly & 12.4 & 18.2 & 8.3 & 31.9 & 20.3 \\
\hline Annually & 32.1 & 12.7 & 26.7 & 22.0 & 17.4 \\
\hline Hardly Ever & 49.6 & 67.3 & 61.7 & 27.7 & 47.8 \\
\hline$N=$ & 137 & 110 & 120 & 141 & 138 \\
\hline \multicolumn{6}{|l|}{ Neighbors } \\
\hline Weekly & $2.4 \%$ & $3.3 \%$ & $1.7 \%$ & $25.2 \%$ & $8.9 \%$ \\
\hline Monthly & 10.5 & 9.8 & 3.4 & 21.8 & 15.4 \\
\hline Annually & 20.2 & 30.1 & 22.0 & 17.7 & 17.9 \\
\hline Hardly Ever & 66.9 & 56.9 & 72.9 & 35.4 & 57.7 \\
\hline$N=$ & 124 & 123 & 118 & 147 & 123 \\
\hline
\end{tabular}


centers on the immediate family, moves outward with less intensity to encompass other relatives and friends, and becomes weaker with those living nearby (neighbors). With such widespread helping networks among relatives and friends, it is likely that neighbors rely more on their own relatives and friends for these kinds of help than upon their neighbors.

To measure family participation, subject were also asked how they spent their time within the previous two week period in various traditional family activities. These included spending time with their family, teaching their children, and visiting parents, relatives and friends. They were also asked to indicate how much time they spent in more urban types of activities. These included spending time in cultural and social clubs, participating in sports activities, watching television, reading, and doing volunteer work for their communities.

Table XVII clearly shows that besides going to the Mosque, especially for men, participants spent a large portion of their time in family-oriented activities. Over $60 \%$ of respondents spent between $26-50$ hours during the two week period with their families and indicates a very strong family orientation. A large amount of time was also spent helping children in their education which is one of the important family functions. Another important indication of the strength in family relations is shown by the high percentage of hours spent visiting family members and relatives. However, among the more urban types of activities, television seems to consume a large portion of people's time. Twenty-five percent of the respondents reported watching television between $26-$ 50 hours during the two week period. Other modern activities such as sports and other city-like activities is expected to compete for more time, as more facilities become available and people move from spending more time in traditional activities, such as visiting and home-oriented activities, to spending more time in modern activities such as social, cultural, and health clubs. 
TABLE XVII

PERCENTAGE OF HOURS SPENT IN ACTIVITIES THE LAST TWO WEEKS

\begin{tabular}{|c|c|c|c|c|c|c|c|}
\hline & \multicolumn{7}{|c|}{ Hours Of Activity } \\
\hline Range Of Hours & $0-2$ & $3-4$ & $5-8$ & $9-15$ & $16-25$ & $26-50$ & $\mathrm{~N}$ \\
\hline At The Mosque & $2.7 \%$ & $18.3 \%$ & $19.6 \%$ & $18.9 \%$ & $12.8 \%$ & $27.7 \%$ & 148 \\
\hline At Home With Family & 0.0 & 1.0 & 4.1 & 21.2 & 13.1 & 60.6 & 99 \\
\hline Helping Children w/ School Work & 6.9 & 11.1 & 20.8 & 27.8 & 8.4 & 25.0 & 72 \\
\hline Visiting Parents/Relatives & 1.2 & 27.2 & 16.0 & 24.7 & 10.5 & 20.4 & 162 \\
\hline Reading At Home & 4.7 & 20.0 & 21.8 & 32.4 & 6.4 & 14.7 & 170 \\
\hline Visiting Friends & 8.4 & 35.8 & 21.8 & 19.6 & 3.3 & 11.1 & 179 \\
\hline At Cultural/Social Clubs & 10.9 & 34.8 & 17.4 & 15.2 & 8.7 & 13.0 & 46 \\
\hline At Sport Club & 1.4 & 30.2 & 19.2 & 16.4 & 16.4 & 16.4 & 73 \\
\hline Watching Television & 3.5 & 14.0 & 14.5 & 34.3 & 8.7 & 25.0 & 172 \\
\hline Volunteer Work & 15.9 & 27.3 & 25.0 & 13.6 & 6.8 & 11.4 & 44 \\
\hline
\end{tabular}

\section{CHILD CARE}

Child care is one of the areas examined by this thesis. It was assumed that families living in the capital area would rely more on outside help for child care. This assumption was initiated by the fact that families in Muscat today live far from their parents, grandparents or other relatives. Such a requirement for child care would be especially needed when the mother goes to work. Table XVIII shows the average hours of child care received within one week, and the number of families with children receiving at least some child care from each source. As indicated, most of the families are still relying on help from within the family. From the child's grandparents, for 
TABLE XVIII

AVERAGE HOURS OF CHILD CARE RECEIVED LAST WEEK FROM:

\begin{tabular}{|l|c|c|c|c|c|c|}
\hline & Grandparent & Sibling & Relative & Housekeeper & Neighbor & Daycare \\
\hline Average Hours & 13.6 & 15.2 & 13.0 & 17.4 & 13.6 & 39.5 \\
\hline $\begin{array}{l}\text { Number } \\
\text { Receiving From }\end{array}$ & 54 & 41 & 28 & 32 & 9 & 2 \\
\hline
\end{tabular}

example, 13.6 hours; from the child's older siblings, 15.2 hours on average per week. There were also 32 families who received 17.4 hours average care from the housekeeper. Relative and neighbors also provided a good amount of child care. The least was Daycare with only 2 families relying on such child care services.

Table XIX illustrates further the point that families today still prefer child care from within the family. Respondents were asked to rank their preference of child care sources in order to measure family members' participation. As shown in Table XIX, older brothers and sisters were preferred as a first or second choice for child care by $90 \%$ of those with children. Grandparents were chosen by $75 \%$ as first or second choice, and other relatives were preferred by $70 \%$ as a first, second, or third choice, with the majority being third choice (58.5\%). Non-relatives (housekeepers, neighbors, and daycare) were clearly not preferred as a means of child care. Neighbors were the least preferred with only $13 \%$ listing them as first through third choice while housekeepers and daycare were the top three choices for about $20 \%$ of those with children.

Table XX shows a comparison of having a foreign housekeeper as a child care source relative to family income. Data from this survey is compared with a study done by the Ministry of Social Affairs and Labor in 1984 which used 160 families. There is an indication that although having a larger income increases the percentage preferring a housekeeper for child care, the majority of respondents preferred not to have a foreign housekeeper. This preference is indicated by over $90 \%$ of those having an income of 
TABLE XIX

PREFERENCE OF CHILD CARE SOURCE

$(1$ = HIGHEST, $6=$ LOWEST $)$

\begin{tabular}{|c|c|c|c|c|c|c|}
\hline Ranks 1-6 & $\begin{array}{c}\text { Child's } \\
\text { Grandparent }\end{array}$ & $\begin{array}{c}\text { Older Sisters/ } \\
\text { Brothers }\end{array}$ & $\begin{array}{c}\text { Other } \\
\text { Relatives }\end{array}$ & Housekeeper & Neighbors & Daycare \\
\hline 1 & $1.2 \%$ & $28.4 \%$ & $4.9 \%$ & $2.9 \%$ & $2.8 \%$ & $3.1 \%$ \\
\hline 2 & 74.4 & 61.4 & 7.3 & 4.3 & 1.4 & 7.8 \\
\hline 3 & 15.1 & 4.5 & 58.5 & 11.4 & 8.5 & 10.9 \\
\hline 4 & 5.8 & 1.1 & 18.3 & 14.3 & 32.4 & 23.4 \\
\hline 5 & 1.2 & 2.3 & 3.7 & 31.4 & 22.5 & 26.6 \\
\hline 6 & 2.3 & 2.3 & 7.3 & 35.7 & 32.4 & 28.1 \\
\hline $\mathrm{N}=$ & 86 & 88 & 82 & 70 & 71 & 64 \\
\hline
\end{tabular}

600 R.O. or less per month. This is perhaps due to the fact that most wives in this category do not work and have no need for outside child care. Another reason is due to the fact that many participants were dissatisfied with foreign housekeepers. Many were concerned about the negative effects of a foreign culture on their children.

TABLE XX

DISTRIBUTION OF FAMILY MONTHLY INCOME AND FAMILY PREFERENCE IN HAVING FOREIGN HOUSEKEEPERS (CHILD CARE)

\begin{tabular}{||c|c|c|c|c|c|c|c|c|c|c||}
\hline \multicolumn{9}{|c|}{ Survey } & \multicolumn{6}{c|}{ Government } \\
\hline & $\begin{array}{c}<300 \\
\text { R.O. }\end{array}$ & $\begin{array}{c}300-600 \\
\text { R.O. }\end{array}$ & $\begin{array}{c}600-900 \\
\text { R.O. }\end{array}$ & $\begin{array}{c}900-1200 \\
\text { R.O. }\end{array}$ & $\begin{array}{c}>1200 \\
\text { R.O. }\end{array}$ & $\begin{array}{c}200 \\
\text { R.O. }\end{array}$ & $\begin{array}{c}600 \\
\text { R.O. }\end{array}$ & $\begin{array}{c}1000 \\
\text { R.O. }\end{array}$ & $\begin{array}{c}1400 \\
\text { R.O. }\end{array}$ & $\begin{array}{c}1800 \\
\text { R.O. }\end{array}$ \\
\hline Yes & $1.4 \%$ & $7.1 \%$ & $43.3 \%$ & $56.2 \%$ & 100.0 & $60.0 \%$ & $28.6 \%$ & $33.3 \%$ & $45.5 \%$ & $45.5 \%$ \\
\hline No & 98.6 & 92.9 & 56.7 & 43.8 & - & 40.0 & 71.4 & 66.7 & 54.5 & 54.5 \\
\hline $\mathrm{N}=$ & 74 & 85 & 30 & 16 & 3 & & & & & \\
\hline
\end{tabular}

Source of Government Data: Ministry of Social Affairs \& Labor, 1984, p. 104.

This study, however, is not consistent with the study by the Ministry of Social Affairs which indicated that $60 \%$ of those in a lower income category do have 
housekeepers. The Ministry's study also shows an increase of percentage of those with higher incomes as having housekeepers.

Table XXI indicates that there is more reliance on a foreign housekeeper when the wife works; $53.7 \%$ versus $11.0 \%$ when the wife does not work. Many of the working wives indicated to the researcher during the survey that they did not feel comfortable leaving their children with a foreign housekeeper. This is corroborated in Table XX. Some of the mothers took their children and their housekeepers to a relative's house during the day. Others who did not have any relatives nearby and had to rely on housekeepers were making telephone calls from their work very frequently to make sure everything was fine at the house. It was indicated to the researcher that such problems are increasingly becoming a concern of the working mother.

TABLE XXI

HOUSEKEEPER BY WIFE WORKING SURVEY RESULT

\begin{tabular}{|c|c|c|}
\hline Housekeeper & Wife Works & Wife Does Not Work \\
\hline Yes & $53.3 \%$ & $11.0 \%$ \\
\hline No & 46.7 & 89.0 \\
\hline $\mathrm{N}=$ & 30 & 91 \\
\hline
\end{tabular}

Table XXII shows the positive and negative effects of a housekeeper on children. Many families were concerned about their children's language with $62.5 \%$ thinking the foreign housekeeper's effect on their children was negative. Children spoke a broken native language and sometimes mixed words from the housekeeper's native language. Religion did not have a large effect. Types of food had some negative effect at $59.6 \%$. Clothes rated $25.5 \%$, and music and movies also had a smaller negative effect at $25.0 \%$. Children learning hobbies from other cultures was not preferred by $60.0 \%$ of the parents. 
TABLE XXII

FOREIGN HOUSEKEEPER EFFECTS ON CHILD

\begin{tabular}{|l|c|c|c|c|c|c||}
\hline & Language & Religion & Food & Clothes & Music/Movies & Hobbies \\
\hline Positive & $37.5 \%$ & $89.1 \%$ & $40.4 \%$ & $74.5 \%$ & $75.0 \%$ & $40.0 \%$ \\
\hline Negative & 62.5 & 10.9 & 59.6 & 25.5 & 25.0 & 60.0 \\
\hline $\mathrm{N}=$ & 48 & 46 & 47 & 47 & 48 & 55 \\
\hline
\end{tabular}

\section{ELDERLY CARE}

It was assumed in this research that as life expectancy improves, special elderly care will be needed. It was also assumed that as young children become involved in modern city life, and have less time to spend with their elderly parents or grandparents, other professional institutions, such as nursing homes, would be needed. However, analysis of the research data indicates that elderly care in Oman is still a family matter. Even though life expectancy in Oman is estimated at 65.2 years, only about a third of the participants who indicated they have elderly parents said that they were unable to care for their parents themselves. See Table XXIII.

TABLE XXIII

TOTAL PERCENTAGE OF FAMILY HAVING ELDERLY WHO CANNOT CARE FOR HIM/HERSELF

\begin{tabular}{|c|c|}
\hline Yes & $32.3 \%$ \\
\hline No & 67.7 \\
\hline $\mathrm{N}=$ & 189 \\
\hline
\end{tabular}


It is also clear that most of the help needed by elderly is in housing, $88.5 \%$, as indicated in Table XXIV. Daily care was least needed at $8.5 \%$. However, such care giving is expected to increase in the coming years as life expectancy improves.

TABLE XXIV

KIND OF HELP MOST ELDERLY NEED

\begin{tabular}{||c|c|c|c|c|c|}
\hline & Housing & Financial & $\begin{array}{c}\text { Daily Care (Cooking, } \\
\text { Washing, Feeding) }\end{array}$ & Transportation & Shopping \\
\hline Yes & $88.5 \%$ & $10.5 \%$ & $8.5 \%$ & $23.1 \%$ & $14.3 \%$ \\
\hline No & 11.5 & 89.5 & 91.5 & 76.9 & 85.7 \\
\hline $\mathrm{N}=$ & 26 & 38 & 47 & 26 & 14 \\
\hline
\end{tabular}

It is traditional in the Middle East, and in Oman particularly, that the oldest son is most responsible in caring for his parents. This belief is supported in Tables XXV and XXVI. Table XXV shows that the participants themselves provided the most help, over $65.0 \%$, to their elderly parents. Brothers and sisters were second and third in importance, at over 55\%., for providing help for the elderly in the family.

TABLE XXV

WHO OFFERS MOST HELP TO ELDERLY IN THE FAMILY

$(1$ = MOST, 8 = LEAST)

\begin{tabular}{||l|c|c|c|c|c|c|c|c|c||}
\hline & 1 & 2 & 3 & 4 & 5 & 6 & 7 & 8 & $\mathrm{~N}$ \\
\hline Self & $65.3 \%$ & $9.3 \%$ & $16.1 \%$ & $4.0 \%$ & $1.3 \%$ & $1.3 \%$ & - & $2.7 \%$ & 75 \\
\hline Brother & 20.4 & 60.9 & 10.1 & 1.4 & 1.4 & 5.8 & - & - & 69 \\
\hline Sister & 18.5 & 15.4 & 55.4 & 6.2 & 1.5 & - & 1.5 & 1.5 & 65 \\
\hline Relative & 6.5 & 9.7 & 6.5 & 62.9 & 12.9 & 1.5 & - & - & 62 \\
\hline Friends & - & - & 1.9 & 9.4 & 34.0 & 22.6 & 22.6 & 9.5 & 53 \\
\hline Neighbor & 3.6 & - & 1.8 & 1.8 & 27.3 & 41.8 & 16.4 & 7.3 & 55 \\
\hline Housekeeper & 8.0 & 2.0 & 4.0 & 8.0 & 8.0 & 4.0 & 24.0 & 42.0 & 50 \\
\hline Government & - & 2.0 & 2.0 & 6.0 & 12.0 & 20.0 & 24.0 & 34.0 & 50 \\
\hline
\end{tabular}


Participants were also asked their opinion as to who should be most responsible for elderly care. As shown in Table XXVI, about $80 \%$ agreed or strongly agreed that the oldest son is held most responsible for elderly parents. Over $70 \%$ thought the oldest daughter is responsible compared to Western societies where the older daughter is most often the elderly care provider. It was also indicated by most of the participants that the government should offer elderly care. This is indicated by over $90 \%$ of participants who thought that both the children and the government are responsible for such care. In fact, $91.3 \%$ of the participants agreed or strongly agreed that the government is responsible for care for those elderly who have no children. It should be pointed out, however, that the government, through the Ministry of Social Affairs, already provides both housing and financial assistance to many such elderly, especially those who are in need and for those disabled.

\section{TABLE XXVI}

ATTITUDES ABOUT WHO SHOULD BE RESPONSIBLE FOR ELDERLY CARE

\begin{tabular}{||l|c|c|c|c|c||}
\hline & $\begin{array}{c}\text { Strongly } \\
\text { Agree }\end{array}$ & Agree & Disagree & $\begin{array}{l}\text { Strongly } \\
\text { Disagree }\end{array}$ & $\mathrm{N}$ \\
\hline Oldest Son & $37.4 \%$ & $42.2 \%$ & $16.1 \%$ & $4.3 \%$ & 211 \\
\hline Oldest Daughter & 25.1 & 52.2 & 15.6 & 7.1 & 211 \\
\hline Any Son or Daughter & 29.5 & 25.1 & 16.4 & 29.0 & 207 \\
\hline Government & 35.1 & 41.5 & 18.0 & 5.4 & 205 \\
\hline $\begin{array}{l}\text { Children and Government } \\
\text { Government for Elderly } \\
\text { With No Children }\end{array}$ & 55.6 & 37.1 & 4.9 & 2.4 & 205 \\
\hline
\end{tabular}

Finally, the subjects were asked from whom they would expect the most care when they became older and needed assistance themselves. As shown in Table XXVII, 
the oldest son is expected by over $60 \%$ of the respondents to be the help provider. Again, the oldest daughter and any of the children were second and third choice respectively. It should be pointed out, however, that the religion of Islam does not put more responsibility on the oldest son or daughter. It does not differentiate between sex or age of the children, but by whoever is able to provide the care.

\section{TABLE XXVII}

FROM WHOM DO YOU EXPECT CARE WHEN YOU BECOME ELDERLY $(1=$ MOST, 8 = LEAST $)$

\begin{tabular}{||l|c|c|c|c|c|c|c|c|c||}
\hline & 1 & 2 & 3 & 4 & 5 & 6 & 7 & 8 & $\mathrm{~N}$ \\
\hline Oldest Son & $60.7 \%$ & $23.6 \%$ & $11.0 \%$ & $1.6 \%$ & $1.6 \%$ & - & $0.5 \%$ & $1.0 \%$ & 191 \\
\hline Oldest Daughter & 11.5 & 44.5 & 24.3 & 11.5 & 4.4 & 3.3 & - & 0.5 & 182 \\
\hline Any Children & 23.0 & 13.4 & 32.6 & 7.0 & 10.2 & 3.7 & 7.5 & 2.6 & 187 \\
\hline Relative & 3.9 & 7.3 & 15.1 & 41.9 & 24.6 & 3.9 & 2.8 & 0.5 & 179 \\
\hline Government & 10.8 & 11.8 & 10.2 & 18.8 & 14.0 & 10.8 & 14.5 & 9.1 & 186 \\
\hline Friends & 1.2 & 1.2 & 3.6 & 7.8 & 26.5 & 42.9 & 10.2 & 6.6 & 166 \\
\hline Neighbors & 0.6 & 1.8 & 1.8 & 4.8 & 10.2 & 28.3 & 42.3 & 10.2 & 166 \\
\hline Housekeeper & 1.9 & 1.3 & 2.5 & 1.9 & 3.1 & 1.3 & 17.6 & 70.4 & 159 \\
\hline
\end{tabular}

Overall, the previous tables indicate that elderly care is still strongly considered a family responsibility. Modern elderly care institutions will be expected and needed, especially with the present generation who moved to the city as young people. These people are cut off from close relatives and their own children may become more involved in the busy city life and have their own family responsibilities. 


\section{CHAPTER V}

\section{SUMMARY}

"Despite the progressive nuclearization of the family, about 14 percent of households in Japan still contain three generations of members" (Isuneo Yamane, reported in Luis Lenero-Otero, 1977, 88). The Yamane study shows $42.8 \%$ extended families among 215 families who participated in the survey. However, the study also found that there is an $8.45 \%$ decrease in extended families from $51.2 \%$ in the parental generation to $42.8 \%$ in the present generation. It was also pointed out in Chapter II that a study completed in Turkey showed about $50 \%$ of village families in Turkey are extended families. In this study, $61.5 \%$ of Muscat government employees living outside the capital were living in extended family types and $38.5 \%$ were nuclear. The same study in Turkey pointed out that there were about $70 \%$ nuclear family types in the capital. This study found that $67.1 \%$ were nuclear families in the capital city of Oman. It was also pointed out in the literature review that Al-Thakeb's analysis of some Arab countries from the 1970 census found that in Egypt, about $77.5 \%$ of families were nuclear. In Bahrain, $94 \%$ were nuclear; in Kuwait, $59 \%$ with $22 \%$ extended and $19 \%$ were quasi-extended or what has become known as modified extended families.

This study indicates that despite the limited years of modern social and economic development in Oman, family structures have shown some changes. These changes were indicated by a large percentage of modified extended family types from about $18 \%$ in the parental generation to over $31 \%$ in the present generation. It was also indicated by more people living further away in the present generation and few people living in the same house or nearby. These changes in the family pattern show that as modernization 
proceeds, families disperse more throughout the country. However, in such an early stage of modernization and as a result of good transportation and communication systems, families stay in strong contact. However, the results also show that on the average, there is less visiting on a daily or weekly basis of relatives among people living in the Muscat than among those living outside the capital area. This evidence indicates that urban dwellers are involved in more modern-like types of activities rather than staying home or visiting relatives and friends. This includes working in their private offices (many government employees have their own businesses which they run after their main government jobs).

It was also shown that the participant's age and father's level of education led to more family nuclearization. It showed that younger children lived with their extended family. However, as age increased they became more independent and formed their own nuclear family. Children of less educated fathers had 50\% extended and 50\% nuclear type families, which indicates that with a low level of education, the lower income forces families to live in extended family types. However, participants who offer regular financial assistance to family members is indicated by over $60 \%$ of the respondents. Short-term accommodations was also a common indication that family members, relatives, and friends come to visit from rural areas on a regular basis, especially for hospitalization or when searching for employment in the city. Neighbors were offered strong support in terms of food (common in Middle East societies, especially during holidays) and clothing.

Overall, this research showed that participants do spend large amounts of their time at home with their families, going to the Mosque, helping their children with school work, and watching television.

Other areas this thesis was concerned with were the issues of child and elderly care. The question was at what level such issues are still a family function. As for child care, this study indicates that child care is still by and large a family matter. Most of the 
respondents received many hours of child care from the child's grandparents and siblings. Housekeepers were a third source of care, but were least preferred. There were also more families where the wife works who relyed on housekeepers than when the wife did not work. It was also found that the housekeeper's most negative perceived effect on the child was in terms of language, hobbies, and the type of food. Other factors, such as religion, clothing, culture, and music or movies were perceived as having a somewhat less negative effect.

Elderly care is the last issue this thesis was concerned with. The elderly care issue in Oman is still a family responsibility as pointed out in this study. Out of 189 respondents, $32.3 \%$ indicated that they have an elderly family member who requires care. Such care, however, was mainly in terms of housing and mobility. A smaller percentage ( $10 \%$ or less) required financial assistance and daily care.

When participants were asked who offers the most help to the elderly in the family, over $65.0 \%$ of respondents answered him/herself. A brother of the respondent scored second with $60.9 \%$, and a sister placed third as a help provider with $55.4 \%$. Other relatives came fourth at $62.9 \%$. Friends, neighbors, housekeepers, and the government were lower and again housekeepers and the government were the least helpful in providing care. Participants also indicated that the oldest son should provide the most help. The oldest daughter came second, any son or daughter came third. The government, by itself, came last. However, the government and children together were the highest with $92.7 \%$ of the 205 participants thinking both the government and elderly children should be responsible for elderly care. However, the government was expected to provide help to the elderly who had no children and no close relations (91.3\%).

Finally, participants were also asked from whom they would expect care the most when they themselves became elderly and in need of care. Again, the oldest son was first choice at $60.7 \%$. The oldest daughter was again second choice and any of the children 
were third choice. Other relatives placed fourth. There were also a large number of the participants (186) who expected the government to offer them help, especially in terms of financial assistance when they retire.

The last question also indicates that elderly care in Oman is still preferred to be handled by the family, although there is an indication that the government sould take part of the responsibility. It should be pointed out, however, that most of the migrants from rural Oman to the capital area are young people who left their parents and relatives behind as they came looking for employment in the city. Elderly parents or relatives might come for a short visit or for advanced hospitalization, but they are not accustomed to city life. They usually prefer to go back and live in the villages as long as they can take care of themselves. It should be pointed out that life expectancy in third world countries in general is not as high as that in the Western societies and modern medical technology is not as readily available in most third world countries. Therefore, many elderly do not live to be very old to be taken care of.

\section{CONCLUSION}

This thesis concludes that despite twenty years of rapid urbanization and modernization, the extended family system in Oman holds strong. This seems to support the argument made earlier that third world countries exhibit a lower rate of family change when compared to Western societies. We can assume in this conclusion that early development in the Western societies reached every corner of the society at faster rates than most third world countries today where development is concentrated in the capitals and major towns. Therefore, it takes a longer time to reach the society as a whole. Furthermore, we can argue that rapid technological development in our time would result in faster effects on society. However, such an effect may not necessarily change our habits or our beliefs at the same rates. To put it differently, we may, for example, change 
our transportation system or live in a different environment such as in the city versus rural village, yet our ideas and beliefs may not reach the same rates of change. Other forces take a longer time to have an effect on our way of life than technology takes.

Another point to be made here is that the nuclear family system in Oman, and in the Middle East in general, is not so isolated from kinship. Family participation is noticeably strong in Oman. Family members are expected to offer help to extended family or relatives when needed. This was indicated by over $60 \%$ of the participants giving financial support to immediate family at least on a monthly basis or by grandparents helping by offering child care.

It is also argued that in the early pre-industrial societies in the West, the extended family mainly existed among the wealthy elite, that is, those who could afford such a living arrangement both in terms of finance and size of housing. In third world societies such an arrangement is not the norm. If the extended family existed among the wealthy class, it is indeed a small percentage. In fact, in Obikeze's study in Nigeria, he reported the contrary. Most wealthy elite families were nuclear and preferred to be so. In Oman, the extended family existence was not necessarily because of wealth, but to keep close family ties. This was looked upon positively and gives the family respected status in the society. Furthermore, the extended family in Oman and in the Islamic societies in general existed mostly because of the polygamous marriage system. Islamic law allows up to four wives at a time. It is a reward for a man to marry more than one wife if such an act solves a social welfare problem, for example, marrying a widow with children. This is a positive act which puts less burden on the state in solving such problems. Such a law also helps after war times when men are killed and many widows are left. The practice of polygamy is more common today within bedouin tribes where multiple marriages are used to form alliances and strengthen kinship ties, and serves to keep the extended family system alive and strong. 
Finally, this research should not be generalized and looked at beyond the limits of the survey participants. It supported some of the studies done in middle eastern societies in terms of strength of family relations despite fast urbanization and modernization. Therefore, a larger, more extensive study would be very helpful to clarify the limits of this research and help us to understand today's family system and structure. 


\section{REFERENCES}

Abdelrahman, A. I. and S. P. Morgan. 1987. "Socioeconomic and Institutional

Correlates of Family Formation: Khartoum, Sudan, 1945 - 75." Journal of Marriage and the Family. Vol. 49, pp. $401-412$.

Al-Fahim, Abdul Rahim. 1989. "200 Sayings and Doings of the Prophet Muhammad." Third Edition. United Arab Emirates.

Al-Thakeb, Fahed. T. 1985. "The Arab Family and Modernity: Evidence from Kuwait." Current Anthropology. 25 (5).

Berman, Harry J. 1987. "Adult Children and Their Parents." Journal of Gerontologoical Social Work. 10.

Berry, Brian J. L. 1981. Comparative Urbanization. St. Martin's Press: New York.

Central Bank of Oman. 1988. Annual Report. Oriental Printing Press. Muttrah, Sultanate of Oman.

Central Bank of Oman. 1989. Annual Report. Oriental Printing Press. Muttrah, Sultanate of Oman.

Danesh, Abol Hussan. 1985. Rural-Urban Migration. Urbanization, and Squatter Settlements in the Developing Countries: A Case Study in Iran. Unpublished dissertation. University of California Dissertation.

Edwards, John N. and Charles H. Page. 1969. The Family and Change. Alfred A. Knopf, Inc.: New York.

Finley, Nancy J. 1989. "Theories of Family Labor as Applied to Gender Differences in Caregiving for Elderly Parents." Journal of Marriage and the Family. 51.

Frankel, Charles. 1963. "The Family in Context." In Helping the Family in Urban Society. Edited by Fred Delliguadri. Columbia University Press: New York.

Gittins, Diana. 1986. The Family in Question. Humanities Press International, Inc.: Atlantic Highlands, New Jersey.

Goode, William J. 1964. The Family. Prentice-Hall, Inc.: Englewood Cliffs, New Jersey.

Goode, William J. 1968. World Revolution and Family Patterns. The Free Press of Glencoe, New York.

Gordon, Michael. 1972. The Nuclear Family in Crisis. Harper and Row: New York. 
Hokenstad, Merl C. 1988. "Cross-National Trends and Issues in Social Service Provision and Social Work Practice for the Elderly." Journal of Gerontological Social Work. 12.

Kelley, A. C. and J. G. Williamson. 1984. "Population Growth, Industrial Revolutions, and the Urban Transition." Population and Development Review. 10, No. 3.

Key, William H. 1969. "Rural-Urban Differences and the Family." In John N. Edwards, The Family and Change. Alfred A. Knopf, Inc.: New York.

Khurshid, A. 1974. The Family in Islam. The Islamic Foundation. Nenelitho, United Kingdom.

Lenero-Otero, Luis. 1977. Beyond the Nuclear Family. Sage Publishing: Beverly Hills, California.

Litwak, Eugene. 1989. "Geographic Mobility and Extended Family Cohesion." In John N. Edwards, The Family and Change. Alfred A. Knopf, Inc.: New York.

Martin, Elmer P. and Joanne Mitchell Martin. 1978. The Black Extended Family. University of Chicago Press.

Ministry of Housing. 1990. Housing in the Sultanate of Oman: Policies, Planning, and Implementation. Unpublished report.

Ministry of Social Affairs and Labor. 1984. A Study on the Effects of Housekeepers on the Omani Family. Unpublished report.

Moore, W. J. 1979. World Modemization: The Limits of Convergence. Elsevier North Holland, Inc. New York.

Nassirpour, Mehdi. 1985. "The Effect of Oil Revenue on the Fertility Pattern in Iran." Journal of Marriage and the Family. 47.

Obikeze, D. S. 1987. "Education and the Extended Family Ideology: The Case of Nigeria." Journal of Comparative Family Studies. 18(1): 21-45.

Ruggles, Steven. 1987. Prolonged Connections: The Rise of the Extended Family in 19 th Century England and America. University of Wisconsin Press.

Stone, Lawrence. 1975. "The Rise of the Nuclear Family in Early Modern England." In The Family in History. Edited by Charles E. Rosenberg. University of Pennsylvania Press, Inc.

Sultanate of Oman Development Council. The Third Five-Year Development Plan 19861990.

Sultanate of Oman, Directorate of National Statistics. 1990. Statistical Year Book 1989. Oriental Printing Press. Muttrah, Sultanate of Oman. 
Sussman, Marvin B. and James C. Roaieis. 1982. "Brief Communications." Human Organization. 41.

Vergin, Nur. 1985. "Social Change and the Family in Turkey." Current Anthropology. 25(5).

Wilson, Mervin N. 1988. "The Black Extended Family: An Analytical Consideration." Developmental Psychology. 22(2). 
APPENDIX A

SURVEY QUESTIONNAIRE

(ENGLISH VERSION) 
This survey questionnaire is designed to ask you about some of your past and present family structures. Some of the questions will be related to your parents' family life in their generation.

The major purpose of this study is to determine how our recent family life structure differs from that of our past generation. An example will be how dilferently we deal with questions such as childcare and elderly care, than our parents.

The outcome of the questionnaire will be used in aggregate form and the study is part of my thesis requirement for a master degree in sociology at Portland State University. Therefore, I ask your full participation; your voluntary time and effort are greatly appreciated.

One final note is that all of the information that you give will be regarded as strictly CONFIDENTIAL and will be used only for the purposes of this study.

\section{PERSONAL BACKGROUND}

1. Nationality: [ ] Omani, [ ] non-Omani

2. Your age _estimate if necessary)

3. You are: I I Male, I ] Female

4. How many brothers and sisters do you have? brothers Sisters

5. What is your present marital status?
[ ] Single
[ ]Married
[ ]Divorced
I JWidowed

If you have never been marriod, please go to question number 9.

6A. How old were you when you first married?

6B. How old was your spouse when you were first married? (estimate if necessary)

7. Does your spouse work for wages?

[ ]Yes [ ]No

8. Do you have children? I ]Yes I JNo If yes, please answer the following:
A. Number of children you have
B. Age of the oldest
C. Age of the youngest

9. About how many years of informal or Quranic education have you had? (Put a "0" if you have had none).

10. How many years of formal schooling have you completed? (Please check the highest level you have had).
[ ] Less than 6 years
[ ] 6 years
[ ] Less than 9 years
[ ] 9 years
[ ] Less than 12 years
[ 112 years
[ ] 2 years of College
[ ] 4 years of college
[ ]M.A. or M.S.
[ ]Ph.D.


11. What is your government nnancial rank?

12. What is the total monthly income of your family? (All income beside your salary, including your spouse's.)
[ ] Under 300 R.O.
[ ] $900-1200 \mathrm{RO}$.
[ ] 300-600 R.O.
[ ] 1200 or over
[ ] 600-900 R.O.

13. Please Indicate, as well as you can recall, where you were living most of the time at each of the ages of your life:

\begin{tabular}{|c|c|c|c|c|c|}
\hline & & Area Where You & Lyed & & \\
\hline $\begin{array}{l}\text { At } \\
\text { Ages }\end{array}$ & $\begin{array}{l}\text { In Capital } \\
\text { Area }\end{array}$ & $\begin{array}{l}\text { In a small town } \\
\text { in Oman }\end{array}$ & $\begin{array}{l}\text { Rural Area } \\
\text { In Oman }\end{array}$ & $\begin{array}{l}\text { A city In } \\
\text { another country }\end{array}$ & $\begin{array}{l}\text { Other } \\
\text { (please specify) }\end{array}$ \\
\hline
\end{tabular}

\begin{tabular}{|c|c|c|c|c|c|}
\hline At Birth & [ ] & [ ] & [ ] & [ J & \\
\hline 1.5 & [ ] & [ ] & [ ] & [ ] & \\
\hline $6-10$ & & [ ] & [ ] & [ ] & \\
\hline $11-15$ & ( ) & [ I & [ ] & [ ] & \\
\hline 16.20 & I ] & [ ] & [ ] & [ ] & \\
\hline $21-25$ & [ ] & [1] & [ ] & [ ] & \\
\hline $26-30$ & [ ] & [ j & [ ] & [ ] & \\
\hline $31-35$ & [ ] & [ ] & [ ] & [ ] & \\
\hline $36-40$ & [ ] & [ ] & {[]} & [ ] & \\
\hline $41-45$ & [ ] & [ ] & [ ] & [ ] & \\
\hline $46-50$ & [ ] & [ ] & {[]} & [ ] & \\
\hline 51 \& Over & & 1 & i j & $i j$ & \\
\hline
\end{tabular}

14. How old were you when you began Uving in a different household from your parents? (If you still live with parents, put zero)

15. Where do you live now?

[ ] In the Capital Area

[ ] Outside the Capital Area

16. Type of housing: ( ] Traditional type

[ ] Modern type I ] Apartment

17. How many rooms are there in your house (Total bedrooms and lining rooms)?

18. Who owns the house in which you live?
( ] self
[ ] spouse's parents
[ ] spouse
I ] povernment
[ J parents
[ ] renting
I I relative

19. If you own your house, how did you obtain the land?

I ] Along with the bouse

[ ] Given by the government

[ ] Bought from Real Estate Agency

[ ] Was Inherited or given as a gift

[ ] Other please spectfy 
20. Please WRITE on the Ilnes below, the number of each type of relative that lives at each distance from you. (Put not applicable for those you do not have.)

\begin{tabular}{|c|c|c|c|c|c|c|}
\hline Relgtive & $\begin{array}{l}\text { Same } \\
\text { house }\end{array}$ & $\frac{\text { Next }}{\text { door }}$ & $\frac{\text { Within }}{\text { walking }}$ & $\begin{array}{l}\text { Within } \\
\text { Driving } \\
\text { Distance }\end{array}$ & $\begin{array}{l}\text { Faraway } \\
\text { or in another } \\
\text { Country }\end{array}$ & $\frac{\text { Not }}{\text { Applicab }}$ \\
\hline \multicolumn{7}{|l|}{ Spouse } \\
\hline \multirow{2}{*}{\multicolumn{7}{|c|}{$\begin{array}{l}\text { Unmarried Chlldren } \\
\text { Married Chlldren }\end{array}$}} \\
\hline & & & - & & - & \\
\hline \multicolumn{7}{|l|}{$\begin{array}{l}\text { Your parents } \\
\text { Unmaried brothers }\end{array}$} \\
\hline \multirow{2}{*}{\multicolumn{5}{|c|}{ Unmarried sisters }} & & \\
\hline & & & & {[} & - & 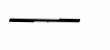 \\
\hline \multirow{2}{*}{\multicolumn{7}{|c|}{$\begin{array}{l}\text { married sisters } \\
\text { your grandparents }\end{array}$}} \\
\hline \multirow{2}{*}{\multicolumn{7}{|c|}{ spouse's parents }} \\
\hline & & & & & & \\
\hline $\begin{array}{l}\text { spouse's grandparents } \\
\text { spouse's brothers }\end{array}$ & & & & & & \\
\hline \multicolumn{7}{|l|}{ spouse's sisters } \\
\hline \multicolumn{7}{|l|}{$\begin{array}{l}\text { your aunts } \\
\text { your uncles }\end{array}$} \\
\hline $\begin{array}{l}\text { your uncles } \\
\text { spouse's aunts }\end{array}$ & & & & & & \\
\hline spouse's uncles & & & & & & \\
\hline
\end{tabular}

21. Please WRTTE the number of relatives on the lines below, that you eat with or visit and how onten. (Put Not Applicabie if you do not have those relatves.)

$\begin{aligned} & \text { Relative } \\ & \text { Neariy }\end{aligned}$
$\begin{aligned} & \text { Every } \\ & \text { Day }\end{aligned}$ $\begin{aligned} & \text { At Least } \\ & \begin{array}{l}\text { Unmarried Children } \\ \text { Married Childrea }\end{array}\end{aligned}$


22. Please WRITE the number of relatives on the lines below that you call up and how often. (Put Not Applicable If you do not have those relatives.)

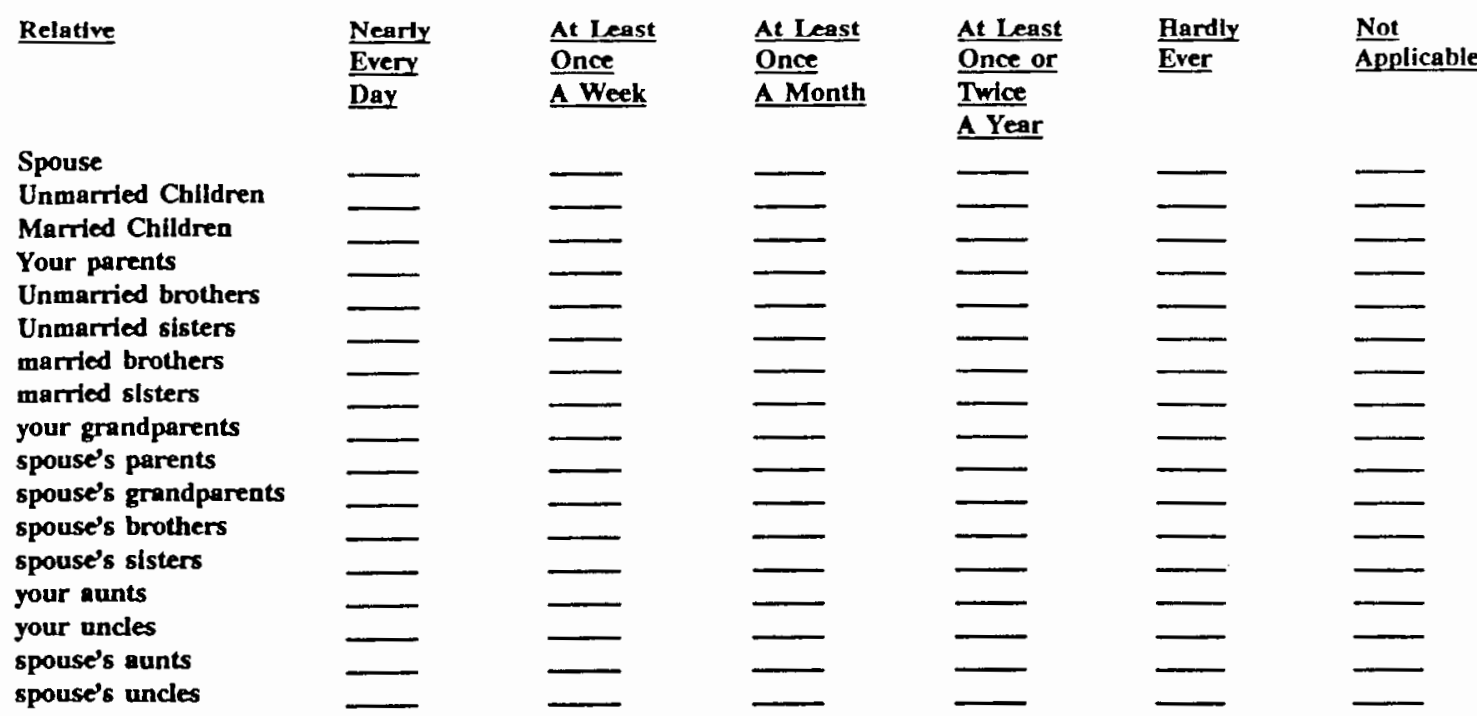

23. You live in your present home because: (check one of the following reasons)

[ I Ministry of Housing's land distribution

[ ] Was given as a gift or Inheritance

[ ] Affordability, of the area

[ ] Your own choice

[ ] O(her (specify)

24. If you were given land or housing closer to your relatives do you think it would help to strengthen family relations.

[ ] Definitely agree

[ ] Probably

[ ] Uncertain

[] Probibly not

[ ] Definitely not

25. You live in the present home because (chouse in order so that number 1 is the first choice and 5 is the last)

[ ] Closeness to your parents or spowse's parents

I I Closeness to your work

I ] Closeness to other relative

[ ] Closeness to your best frtends

[ ] This is the area you prefer most 


\section{FAMILY PARTICIPATION}

26. How often, In the past year have you provided the following help to Immediate family, other relatives, friends, and neighbors?

\begin{tabular}{|c|c|c|c|c|c|}
\hline Relations & $\begin{array}{l}\text { Type of } \\
\text { Help }\end{array}$ & $\frac{\text { About }}{\text { Once }}$ & $\begin{array}{l}\frac{\text { About }}{\text { Once }} \\
\text { amonth }\end{array}$ & $\begin{array}{l}\frac{\text { Abont }}{\text { Once or Twice }} \\
\text { a year }\end{array}$ & $\begin{array}{l}\text { Never } \\
\text { or Hardly Ever }\end{array}$ \\
\hline $\begin{array}{l}\text { Immediate } \\
\text { Famlly } \\
\text { (Parents, } \\
\text { Brothers, } \\
\text { Sisters, } \\
\text { Grandparen }\end{array}$ & $\begin{array}{l}\text { Finandial } \\
\text { Food \& Clothing } \\
\text { Finding Employment } \\
\text { Short Accommodation } \\
\text { Marriage advicel } \\
\text { (L) problem solving }\end{array}$ & $\begin{array}{ll}1 & ] \\
1 & ] \\
{[} & 1 \\
{[} & 1 \\
1 & ]\end{array}$ & $\begin{array}{ll}{[} & ] \\
{[} & ] \\
{[} & ] \\
{[} & ]\end{array}$ & $\begin{array}{ll}{[} & ] \\
{[} & ] \\
{[} & ] \\
{[} & ] \\
{[} & ]\end{array}$ & $\begin{array}{ll}1 & ] \\
{[} & ] \\
1 & ] \\
{[} & ] \\
{[} & 1\end{array}$ \\
\hline $\begin{array}{l}\text { Other } \\
\text { Relatives }\end{array}$ & $\begin{array}{l}\text { Financial } \\
\text { Food \& Clothing } \\
\text { Finding Employment } \\
\text { Short Accommodatioa } \\
\text { Marriage advice/ } \\
\text { problem solving }\end{array}$ & $\begin{array}{ll}{[} & ] \\
{[} & ] \\
{[} & ] \\
{[} & ] \\
{[} & ]\end{array}$ & $\begin{array}{ll}{[} & ] \\
{[} & ] \\
{[} & ] \\
{[} & ] \\
{[} & ]\end{array}$ & $\begin{array}{ll}{[} & ] \\
{[} & ] \\
{[} & ] \\
{[} & ] \\
{[} & ]\end{array}$ & $\begin{array}{ll}{[} & ] \\
{[} & ] \\
{[} & ] \\
{[} & ] \\
{[} & ]\end{array}$ \\
\hline Friends & $\begin{array}{l}\text { Financial } \\
\text { Food \& Clothing } \\
\text { Finding Employment } \\
\text { Stort Accommodation } \\
\text { Marriage advice/ } \\
\text { problem solving }\end{array}$ & $\begin{array}{ll}{[} & ] \\
{[} & ] \\
{[} & ] \\
{[} & ] \\
{[} & ]\end{array}$ & $\begin{array}{ll}{[} & ] \\
1 & ] \\
{[} & ] \\
{[} & ] \\
{[} & ]\end{array}$ & $\begin{array}{ll}{[} & ] \\
{[} & ] \\
{[} & ] \\
{[} & ] \\
{[} & ]\end{array}$ & $\begin{array}{ll}{[} & ] \\
{[} & 1 \\
{[} & 1 \\
{[} & 1 \\
{[} & ]\end{array}$ \\
\hline Neighbors & $\begin{array}{l}\text { Finanelal } \\
\text { Food \& Clothing } \\
\text { Finding Employment } \\
\text { Short Accommodation } \\
\text { Marriage advice/ } \\
\text { problem solving }\end{array}$ & $\begin{array}{ll}{[} & ] \\
{[} & ] \\
{[} & ] \\
{[} & ] \\
{[} & ]\end{array}$ & $\begin{array}{ll}\text { I } & ] \\
{[} & ] \\
{[} & 1 \\
\text { [ } & ]\end{array}$ & 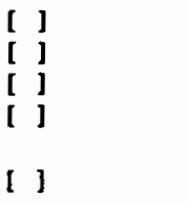 & $\begin{array}{ll}{[} & ] \\
{[} & ] \\
{[} & ] \\
{[} & ] \\
{[} & ]\end{array}$ \\
\hline
\end{tabular}

27. For the last two weeks, about how many hours did you spend in the following areas: (indicate the total hours)

At the Mosque

At bome with your immedlate family

Teaching or helping your chlldren in school work

Visiting your parents or other relatives

At home reading

Visiting friends

At a cultural or social club

At a sports ciub or participating in sports

At home watching T.Y.

Doing a volunteer work for your community 
III. CHID CARE: If you do not have children please go to question 33.

28. Do you receive child care help?

[ ] Yes [ ] No If no, please go to question 33.

29. Last week, about how many hours of child care did your child receive from the following?

Child's Grandparents

The Child's odder sisters or brothers

Other relatives

Housekeepers

Neighbors

Day care or preschool

Other : specify

30. Fram whom do you prefer receiving child care? (Put in onder so that 1 is most preferred and 6 is least preferred.)

Child's Grandparents

The Child's older sisters or brothers

Other relotives

Housekeepers

Neighbors

Day care or preschood

31. Do you have a forelgn bousekeeper for child care?

[ ] Yes [ ] No; If no, go to question number 33.

32. What are the positive and negative effects on your children, caused by a foreign servant? (please put a + beside positive and - beside negative effects).

I I Exposure to forelgn language

(] Exposure to difrerent religion

[ 1 Expocure to different types of lood

[ ] Exposure to different clothes

[ ] Exposure to different music, movies, etc.

[ ] Exposure to different games, hobbies, etc.

IV. The Elderly

33. Among your brothers and sisters, are yous

I I The youngest [ ] The Oldest I I The Middle child I I Only child

34. Within your family or among your relatives, is there any elderly person that cannot care for him/herself and who needs special care on a regular basis?

[ ] Yes [ ] No ; If no please go to question 38. 
35. What kind of help does the elderiy person need? (Check as many that apply).

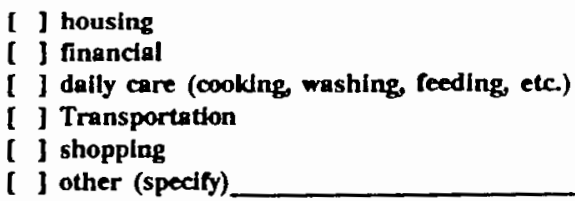

36. What knd of help do you provide for your elderly relative? (Check as many that apply)

[ ] housing

[ ] financlal

[ ] dally care (cooking, washing, fceding, etc.)

[ ] Transportation

[ ] shopping

[ ] other (specify)

37. If an elderly person in your tamily needs belp (such as those kfinds mentioned in question 35 and 36 ) on a regular basis, who offers the most help? (put 1 as the most and 8 as the least help giver).

Yourself
Your brother(s)
Your Sister(s)
Yelative(s)

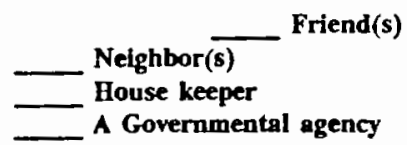

38. The oldest son shonld provide elderly care to his parents or grandparents.

[ ] Strongly agree [ ] agree [ ] disagree [ ] Strongly disagree

39. The oldest daughter should provide elderly care to ber parents or grandparents.

[ ] Strongly agree [ ] agree [ ] disagree [ ] Strongly disagree

40. It does not matter which son or daughter provides elderly care to their parents or grandparents.

[ ] Strongly agree [ ] agree [ ] disagree [ ] Strongly disagree

41. The govemment should provide homes and services for the elderly.

[ ] Strongly agree [ ] agree [ ] disagree [ ] Strongly disagree

42. The elderly care should be a responsibility of both the children and the government.

[ ] Strongly agree [ ] agree [ ] disagree [ ] Strongly disagree

43. The goversment should provide homes and services only for the elderly who have no children or close relatives.

[ ] Strongly agree [ ] agree [ ] disagree [ ] Strongly disagree

44. When you become an elderly and in need of special care, from whom would you expect the most help (put 1 as the most preferred and 8 as the least preferred). Relative(s)

the government

any of your other children

Oldest son

friend(s)

Oldest daughter

house keepers

neighbor(s) 


\section{RECOLLECTIONS}

The following questions, ask you to THINK RACK to your parents' life and your life as you were living with your parents around the time when you were 15 years old.

45. How old were your parents when they first married?

Father's first marriage Mother's first marriage

46. How many brothers and sisters did your father and mother have?

Father Mother

47. What level of education did your father and mother have (please check the highest level)?

\begin{tabular}{cll} 
Father & & \multicolumn{1}{c}{ Mother } \\
\hline [ ] & [ ] & No education \\
[ ] & [ ] & Informal or Quranic education \\
[ ] & [ ] & Elementary education \\
[ ] & [ ] & Secondary education \\
[ ] & [ ] & College education \\
[ ] & [ ] & Beyond college education
\end{tabular}

48. Did or do your parents work for wages?

Father [ ] Yes [ ]No

Mother [ ] Yes [ ]No

49. If you have knowiedge of your father's residence before you were born, where did YOUR FATHER live when he was the following age?

\begin{tabular}{|c|c|c|c|c|c|}
\hline & $\begin{array}{l}\text { In } \\
\text { Capital } \\
\text { Arteg }\end{array}$ & $\begin{array}{l}\text { In a } \\
\text { Small town } \\
\text { In Oman }\end{array}$ & $\begin{array}{l}\text { Rural } \\
\text { Area In } \\
\text { In Oman }\end{array}$ & $\begin{array}{l}\text { A City } \\
\text { in another } \\
\text { Country }\end{array}$ & Other (please specify) \\
\hline At Birth & [] & [ ] & [] & {[]} & $\therefore$ \\
\hline at age 16 & [ ] & [ ] & [ ] & [ ] & \\
\hline $\begin{array}{l}\text { at marriage } \\
\text { at birth of his }\end{array}$ & [ ] & [ ] & [ ] & [ ] & \\
\hline first child & [ ] & [ ] & [ ] & [ ] & \\
\hline Now & [ ] & [ ] & [ ] & [ ] & \\
\hline
\end{tabular}


50. As tar as you can remember, Please write the number of relatives on the lines below and how (ar they lived from YOUR PARENTS most of the time. (Check Not Applicable if they did not have the specific relatives)

Relative
Their Unmartied Children Their Martied Children Your Father's Parents Your Mother's Parents Your Father's Brothers Your Mother's Brothers Your Father's Sisters Your Mother's Sisters Your Father's Aunts Your Mother's Aunts Your Father's Uncles Your Mother's Undes

$\begin{array}{ll}\text { Same } & \text { Next } \\ \text { house } & \text { doo }\end{array}$

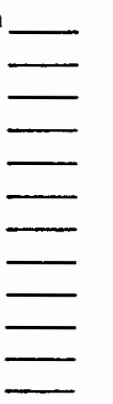

\section{$\frac{\text { Next }}{\text { door }}$}

\section{Within walking Distance \\ Within Driving Distance}

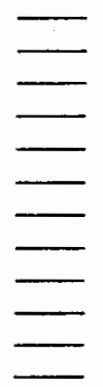

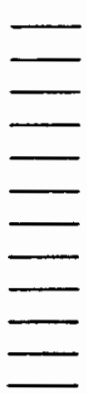

\section{Faraway Not or in another Applicable Country}

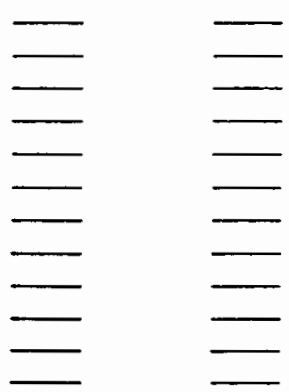

51. As far as you can remember, how often did your parents eat with or visit the following, Please write the number of each relative on the lines below.

Relative
$\begin{aligned} & \text { Nearly } \\ & \text { Their Unmarried Children }\end{aligned}$
Their Married Children
Your Father's Parents
Your Mother's Parents
Your Father's Brothers
Your Mother's Brothers
Your Father's Sisters
Your Mother's Sisters
Your Father's Aunts
Your Mother's Aunts
Your Father's Uncles
Your Mother's Uncles

52. As far as you can remember, how oftem did your parents offer a help to other relatives?

[ ] very often [ ] quite often [ ] once in a while [ ] no help was given

53. If your grandparents or other elderly rejatives needed special care on a regular basis, who in your opinion should give them the most belp? (Put $l$ as the most care provider and 6 as the least).

[ ] your parents [ ] neighbors

[ ] yourself [ ] House Keeper

[ ] other relatives [ ] no help was given

[ ] a government agency 
54. As far as you remember, when you were a child, who took care of you, besides your parents, on a regular basis? ( put 1 as the most care given and 8 as the least)

grandparents

An older brother

other relative(s)

An older sister

aunt/uncle neighbor(s)

house keeper

$$
\text { day care }
$$$$
\text { no one }
$$

THANK YOU AGAIN FOR PARTICIPATING. IF YOU BAVE ANY QUFSTIONS REGARDING THIS SURVEY, PLEASE CONTACT:

SULTAN AL-RASHMU

Telephone \#: 513-333 Ext. 1687

S.Q.U. Sultangte of Oman 
APPENDLX B

SURVEY QUESTIONNAIRE

(ARABIC VERSION) 


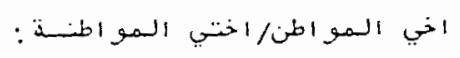

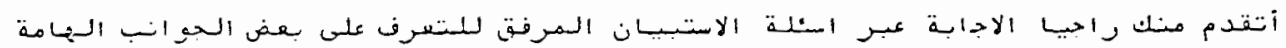

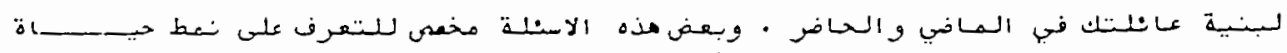

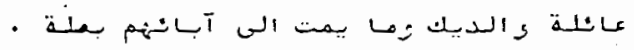

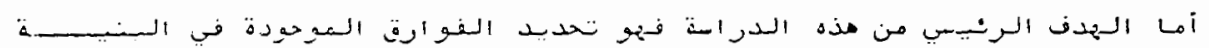

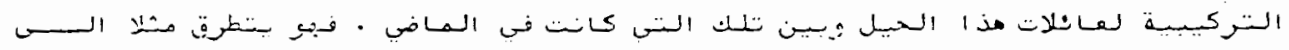

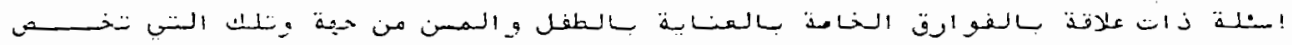

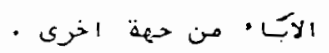

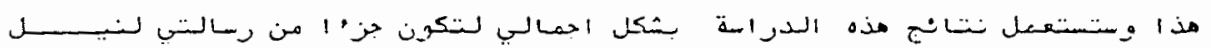

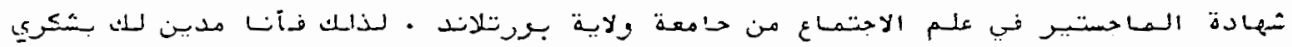

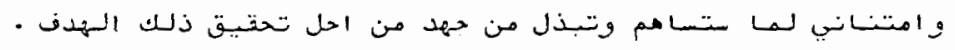

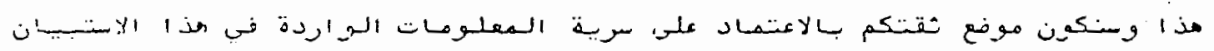

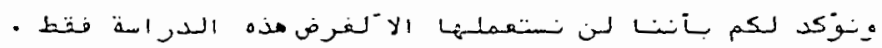

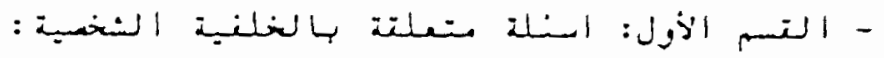

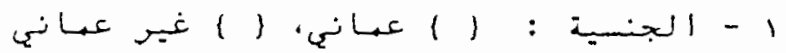

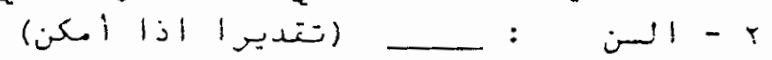

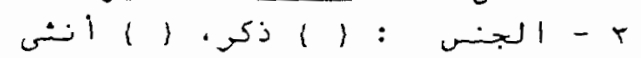

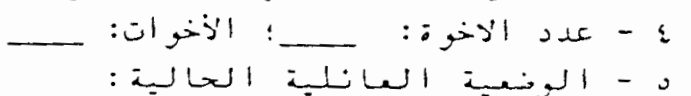

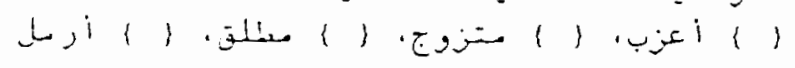

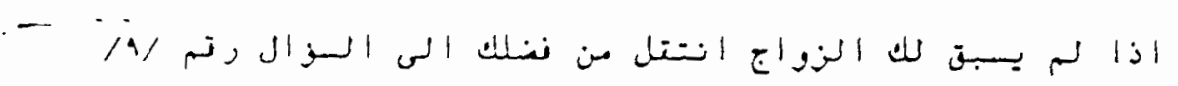

ר

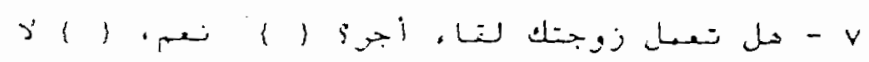

$$
\begin{aligned}
& \text { ○ }
\end{aligned}
$$




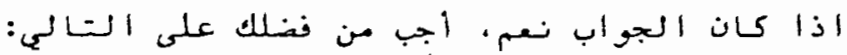

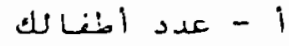

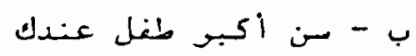

$$
\begin{aligned}
& \text { ج - من أصغو طفل عند عند عند }
\end{aligned}
$$

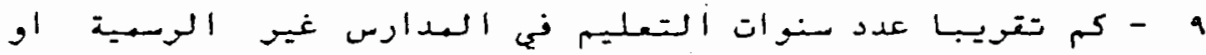

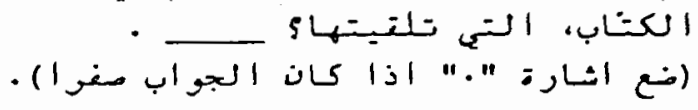

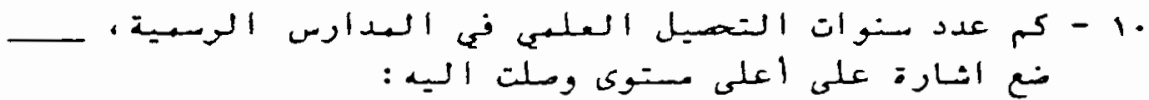

$$
\begin{aligned}
& \text { ) }
\end{aligned}
$$

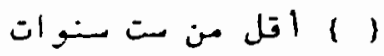

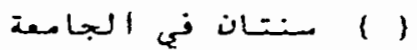

$$
\begin{aligned}
& \text { ( ) }
\end{aligned}
$$

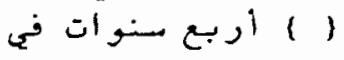

$$
\begin{aligned}
& \text { | أتل من تسع مستوات ات ات }
\end{aligned}
$$

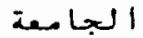

(1)

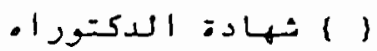

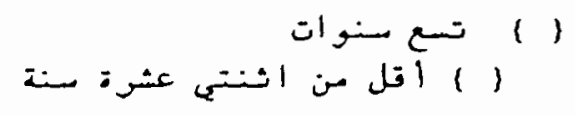

$$
\text { 1Y }
$$

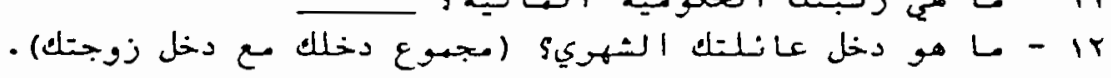

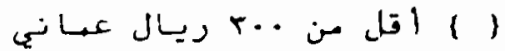

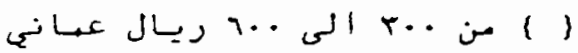

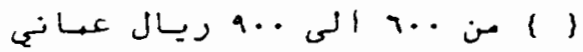

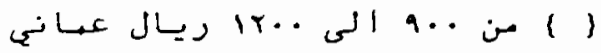

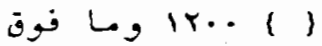




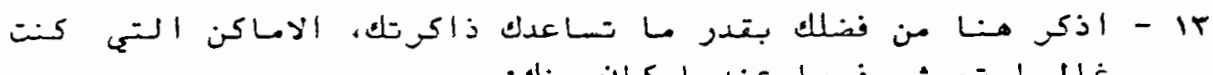

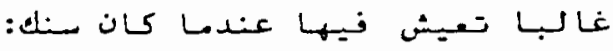

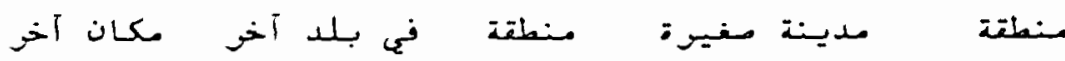
حلدمن فيلي $2+2$ ;

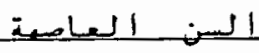

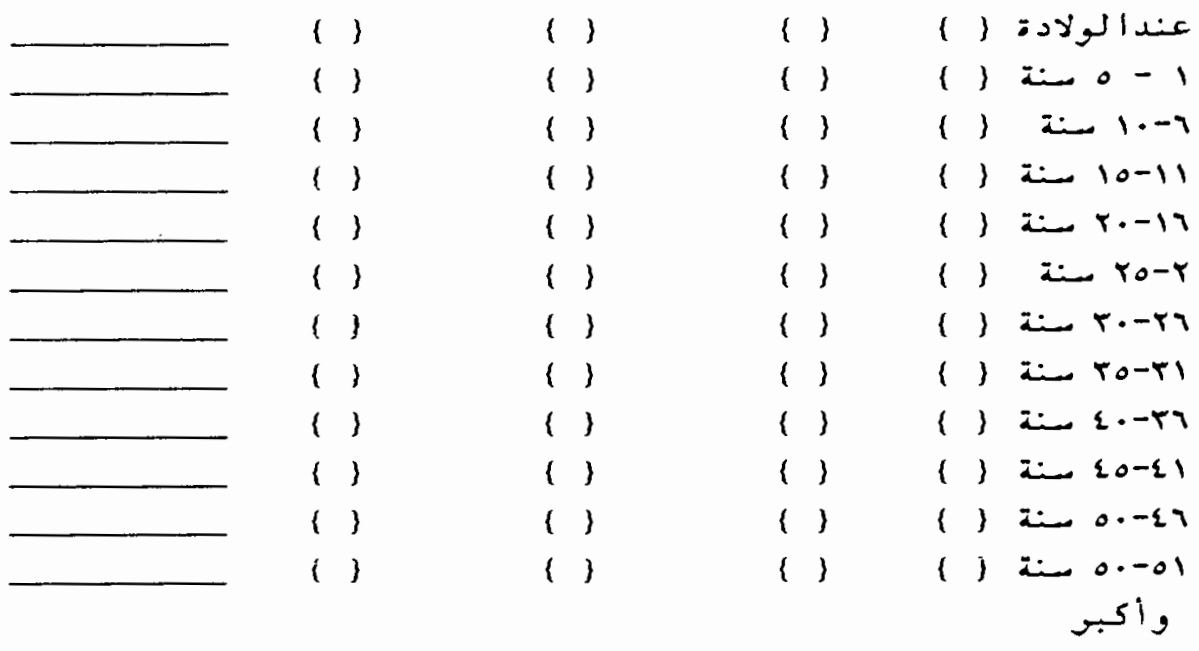

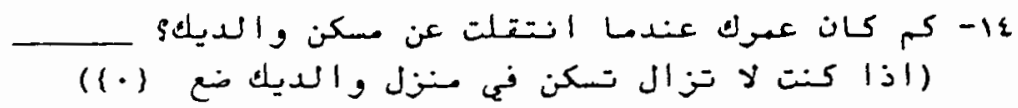

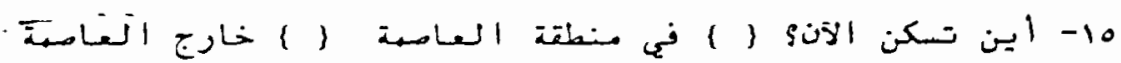

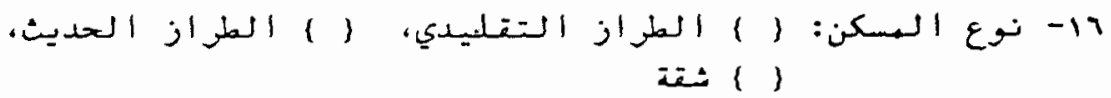

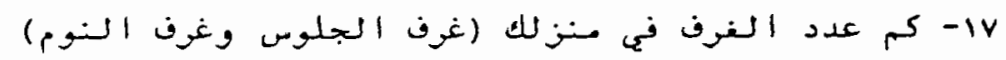

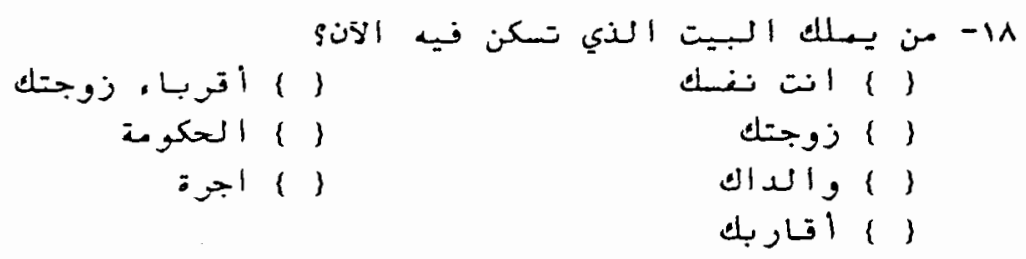




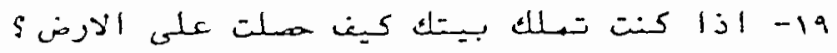

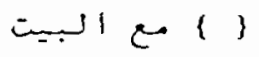

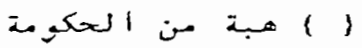

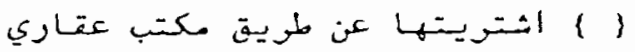

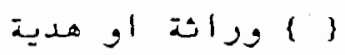

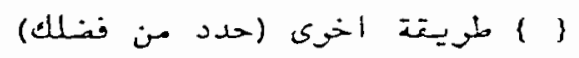

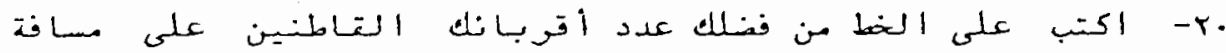

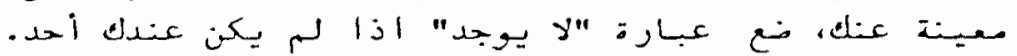

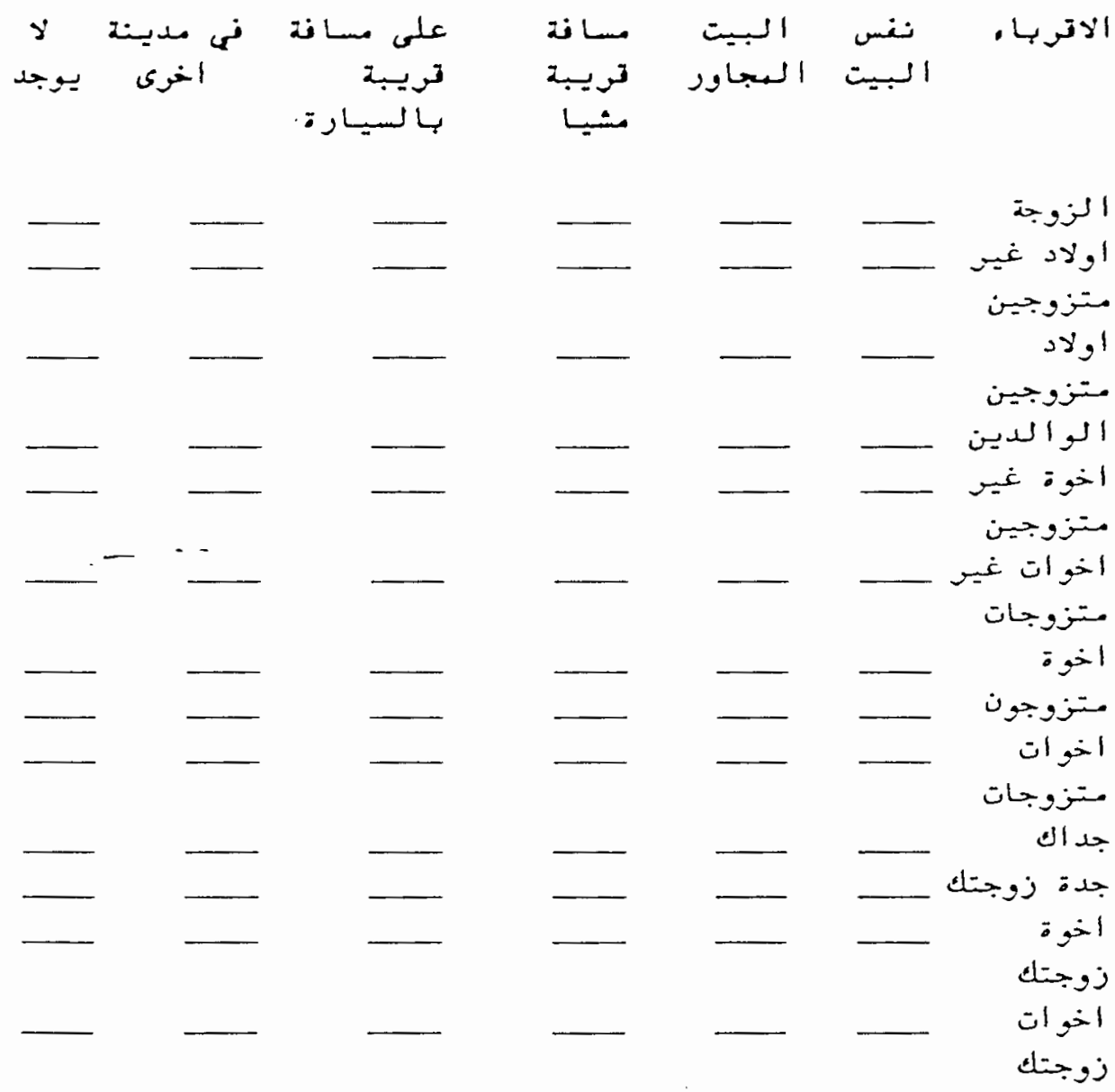




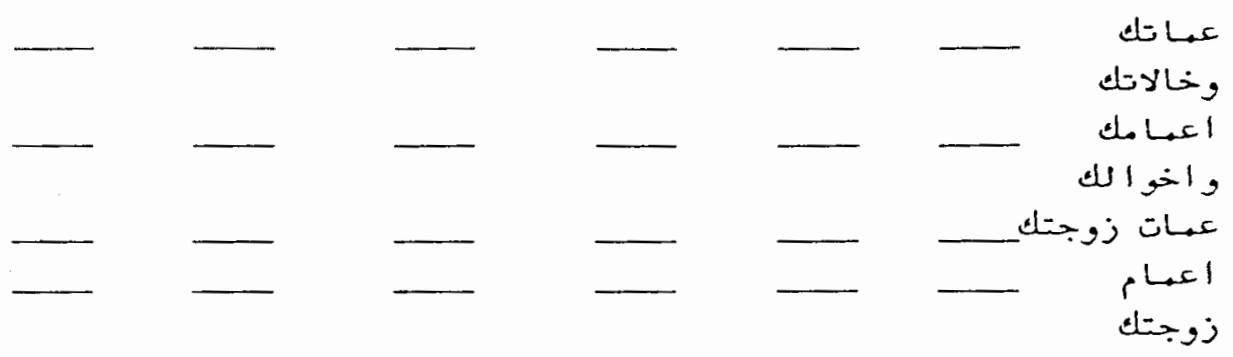

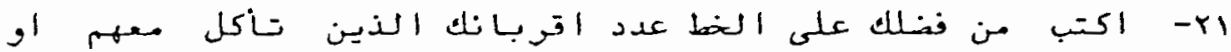

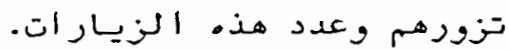

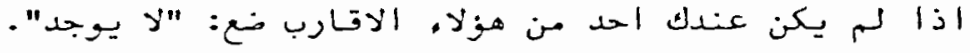

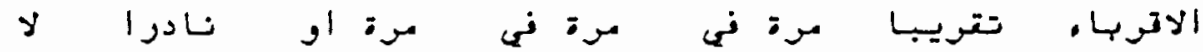

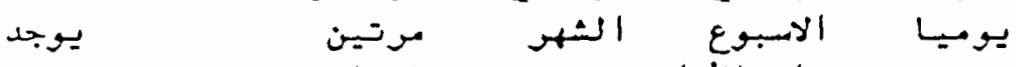

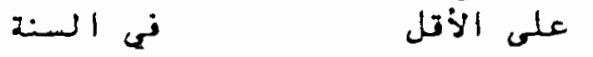

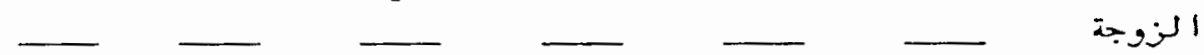

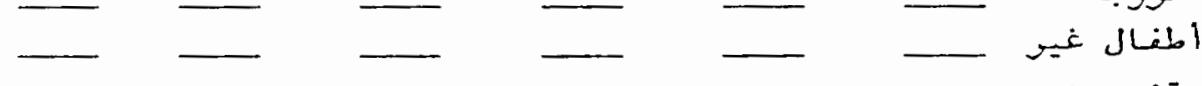
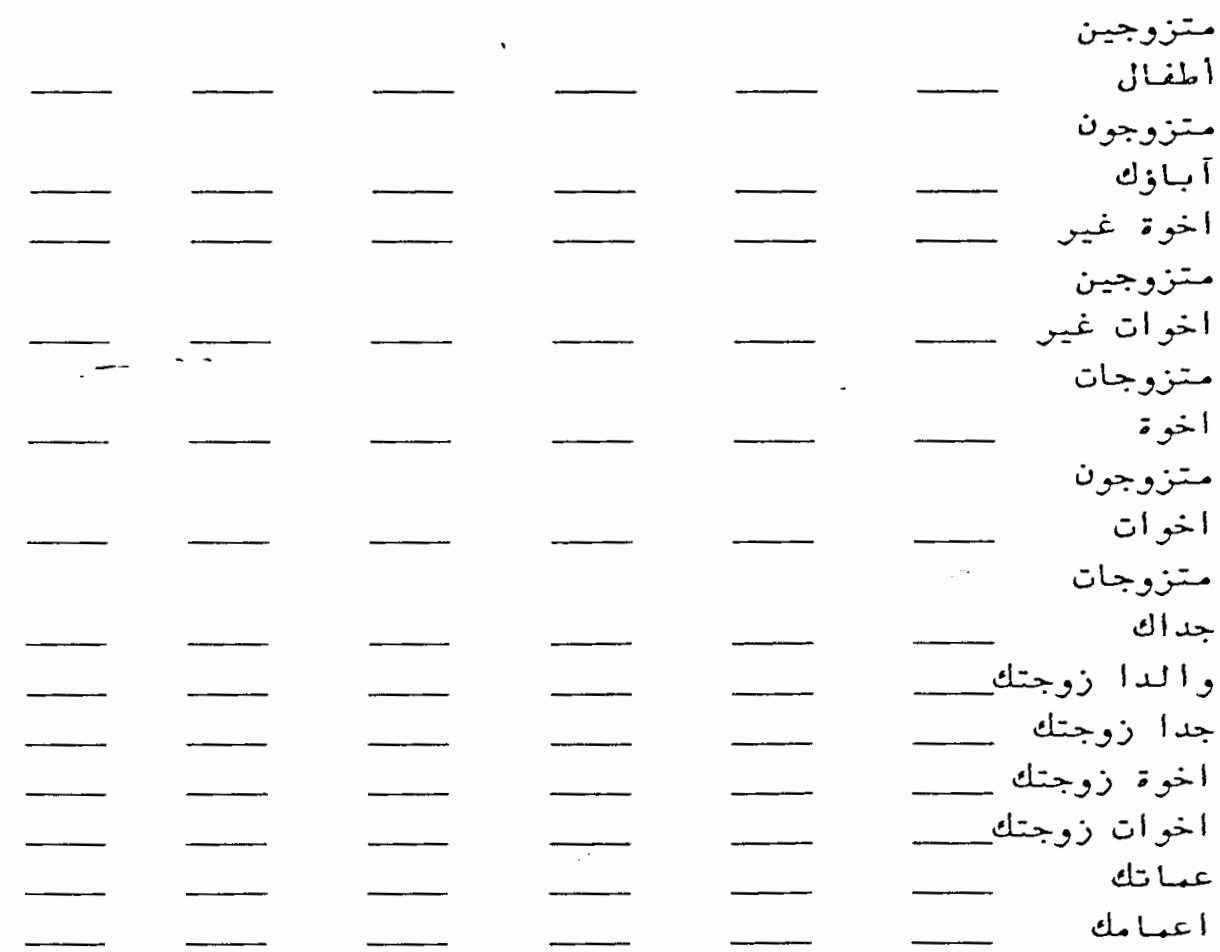
(7)

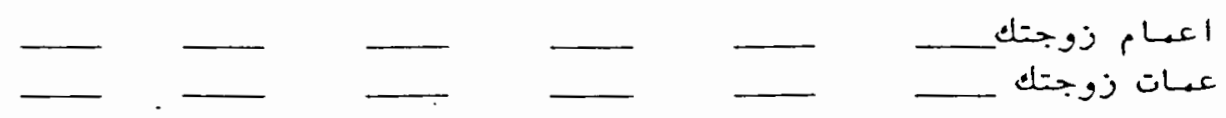

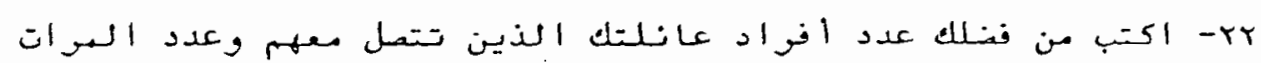

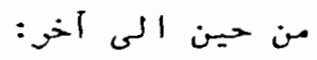

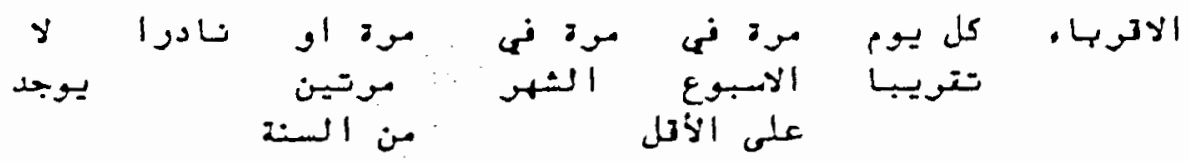

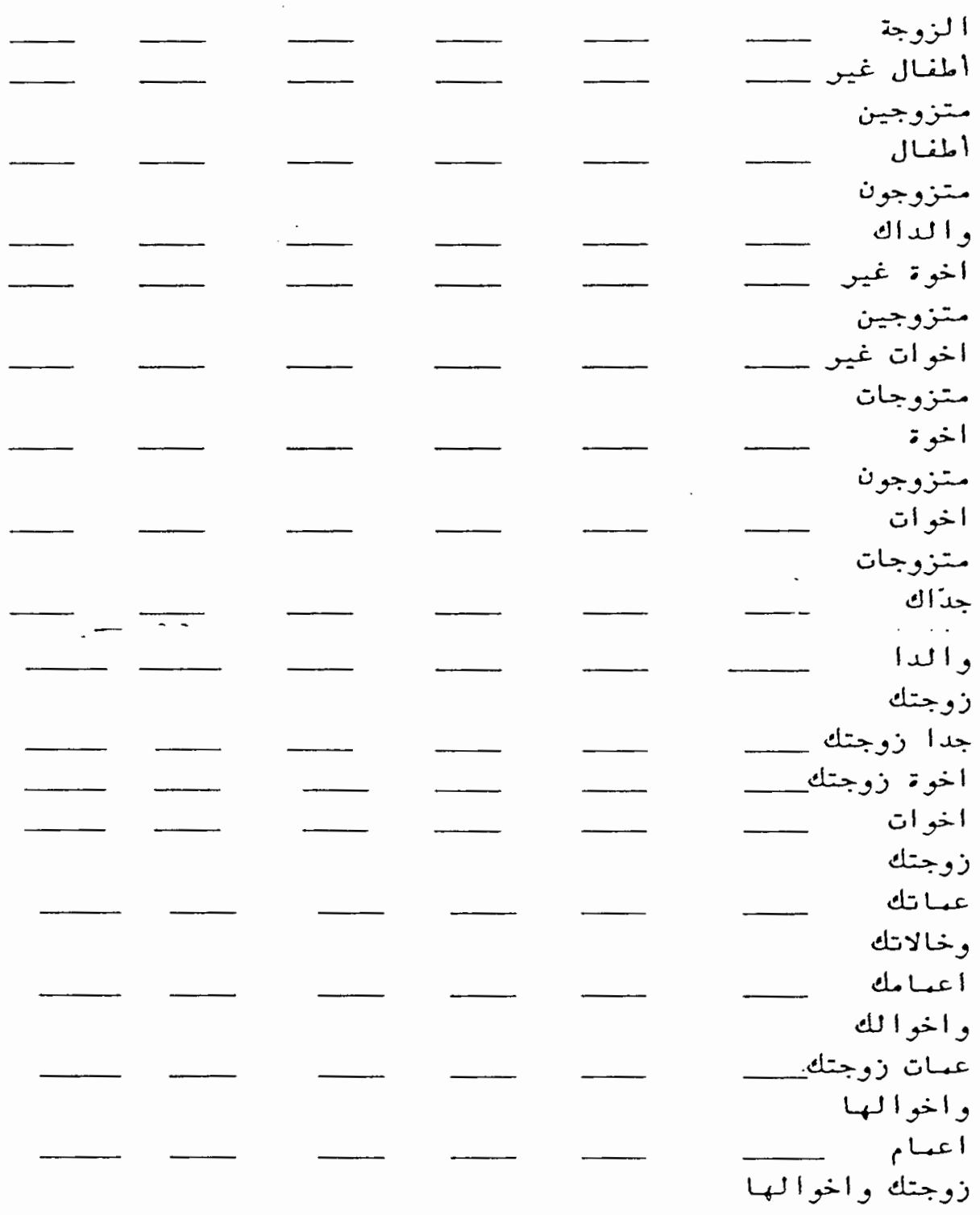




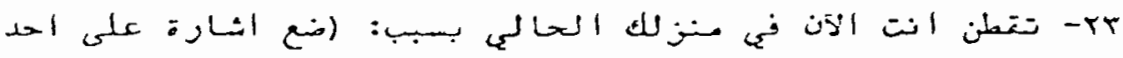
الاسبـاب الهـالدية) : تلان

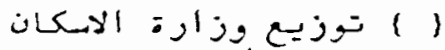

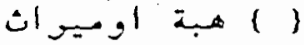

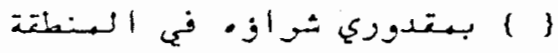

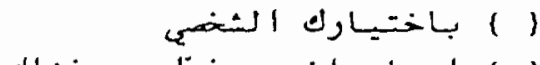

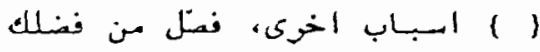

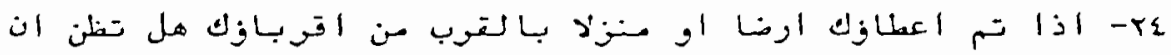

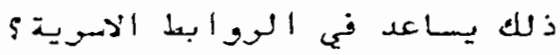

$$
\begin{aligned}
& \text { ا }
\end{aligned}
$$

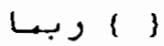

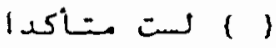

$$
\begin{aligned}
& \text { ( ) (1) }
\end{aligned}
$$

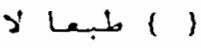

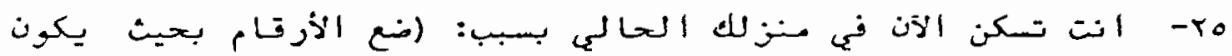

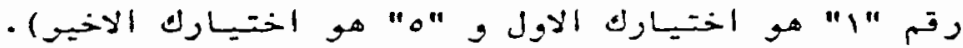

$$
\begin{aligned}
& \text { ( ) قوبك من و الديك او : الدي زو:جتك } \\
& \text { ) } \\
& \text { ) }
\end{aligned}
$$

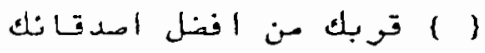

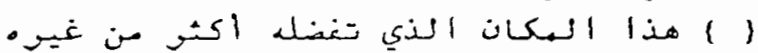




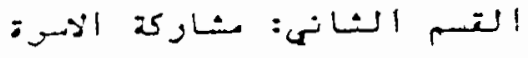

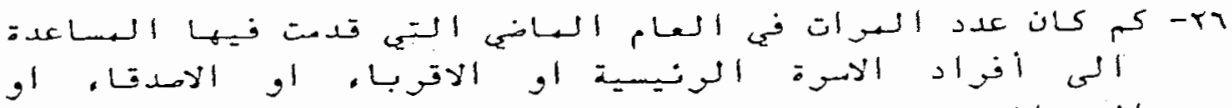

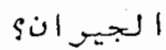

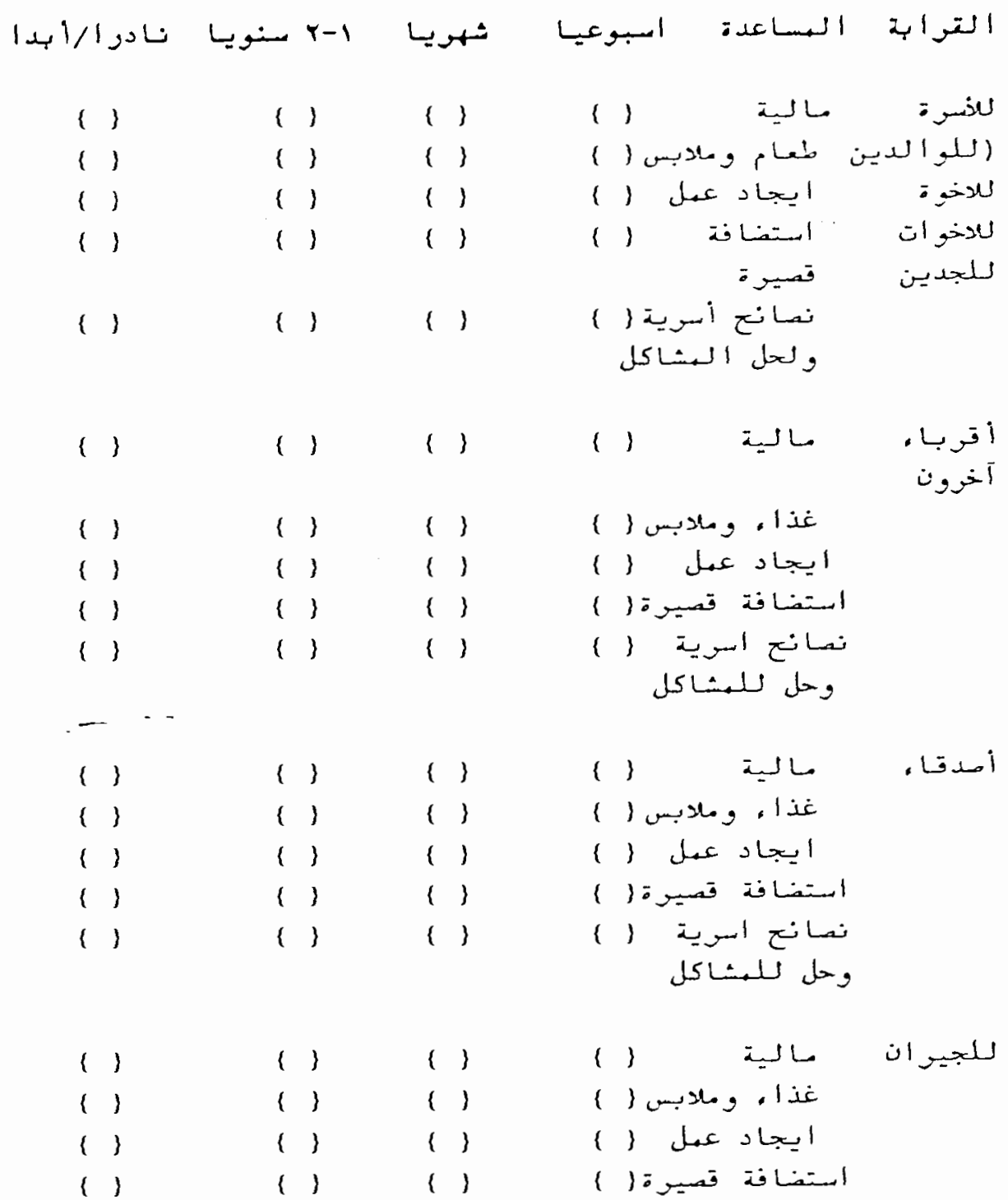


(9)
(1)
( )
()

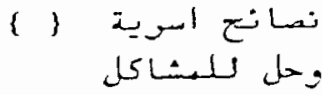

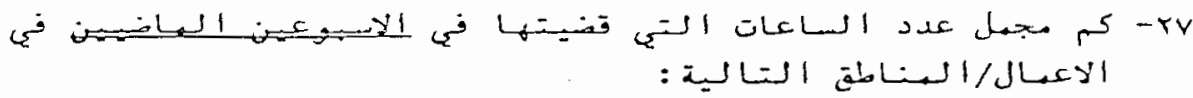

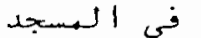

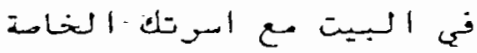

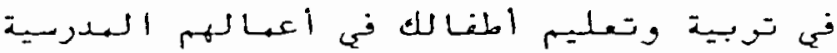

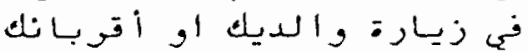

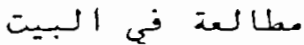

$$
\begin{aligned}
& \text { في زيارة الاهدقاء الدئ }
\end{aligned}
$$

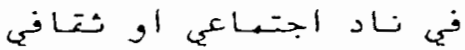

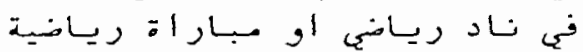

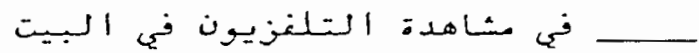

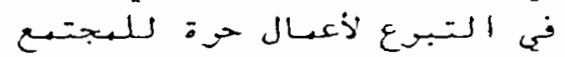

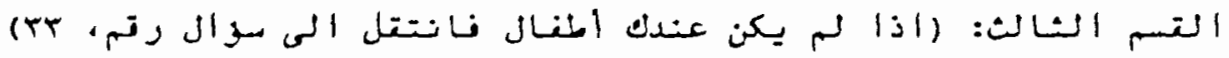

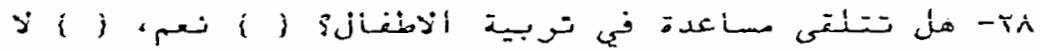

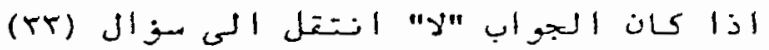

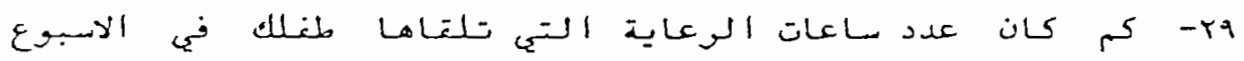

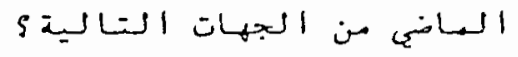

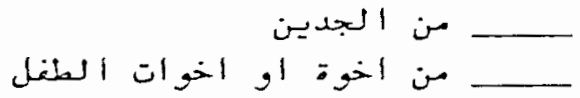

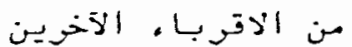

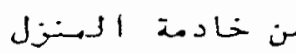

$$
\begin{aligned}
& \text { - من الجيو الجيان }
\end{aligned}
$$

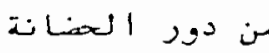

$$
\begin{aligned}
& \text { من جهة اخرى (حدد من فضلك) }
\end{aligned}
$$




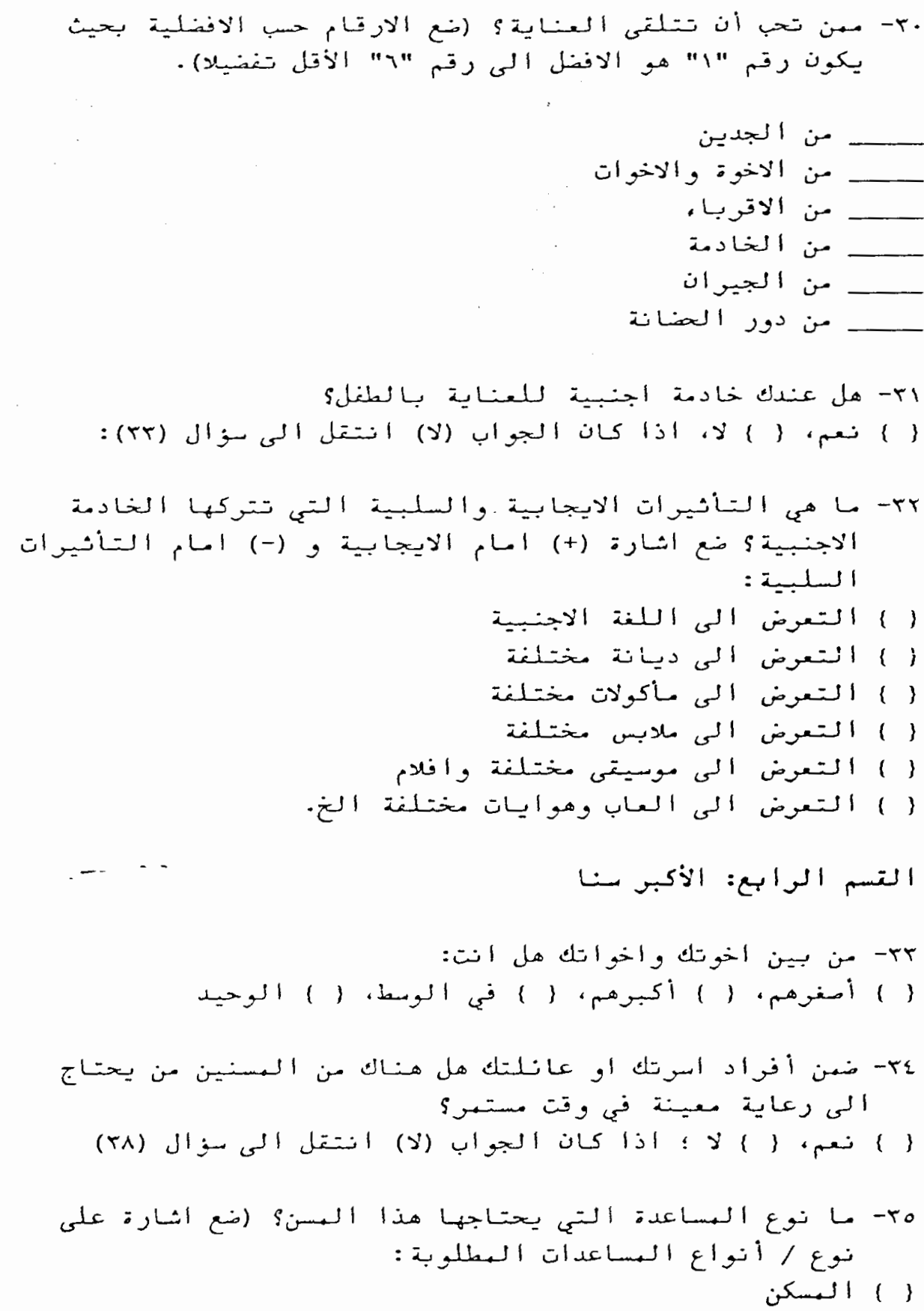


(11)

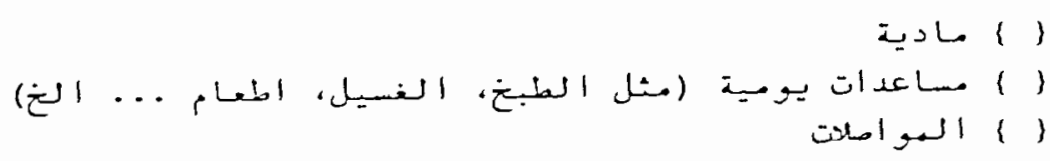

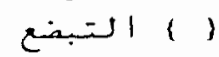

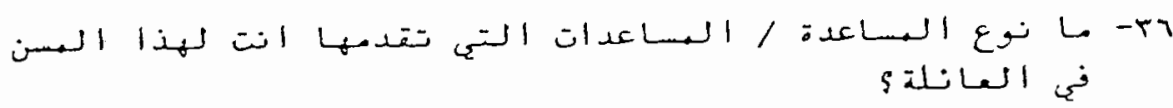

$$
\begin{aligned}
& \text { (1) } \\
& \text { 2Lد }\{1
\end{aligned}
$$

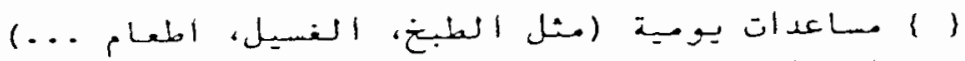

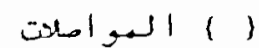

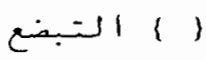

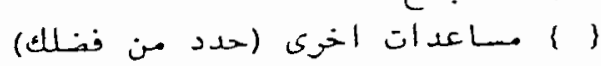

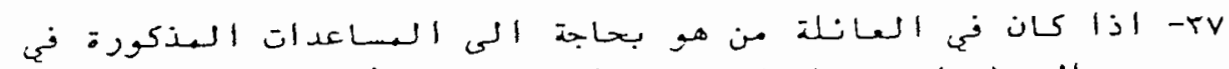

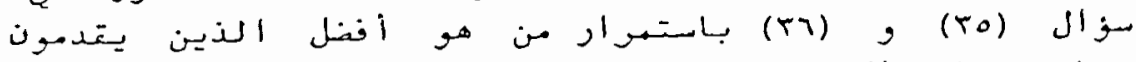

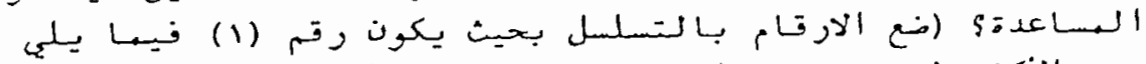

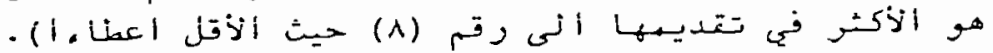

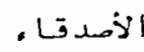

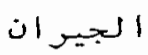

$$
\begin{aligned}
& \text { الخادير الندا }
\end{aligned}
$$

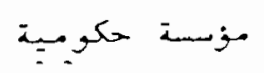

$$
\begin{aligned}
& \begin{array}{r}
- \\
-
\end{array}
\end{aligned}
$$

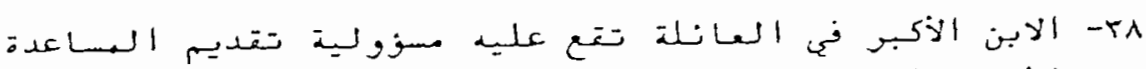

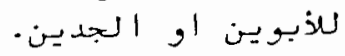

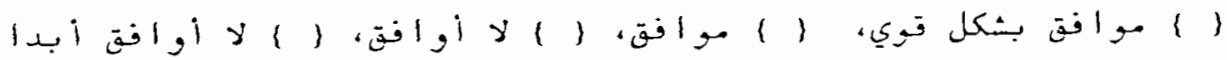

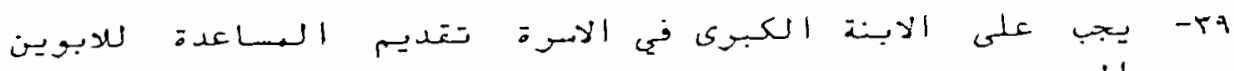

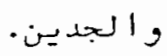

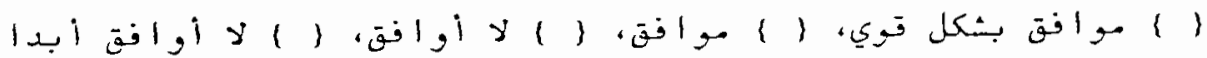

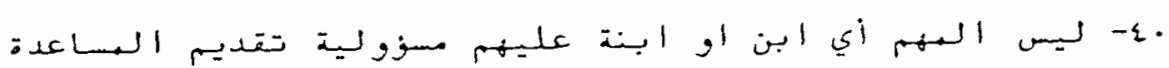

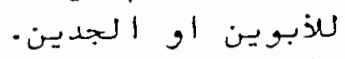

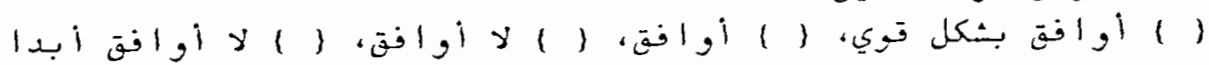




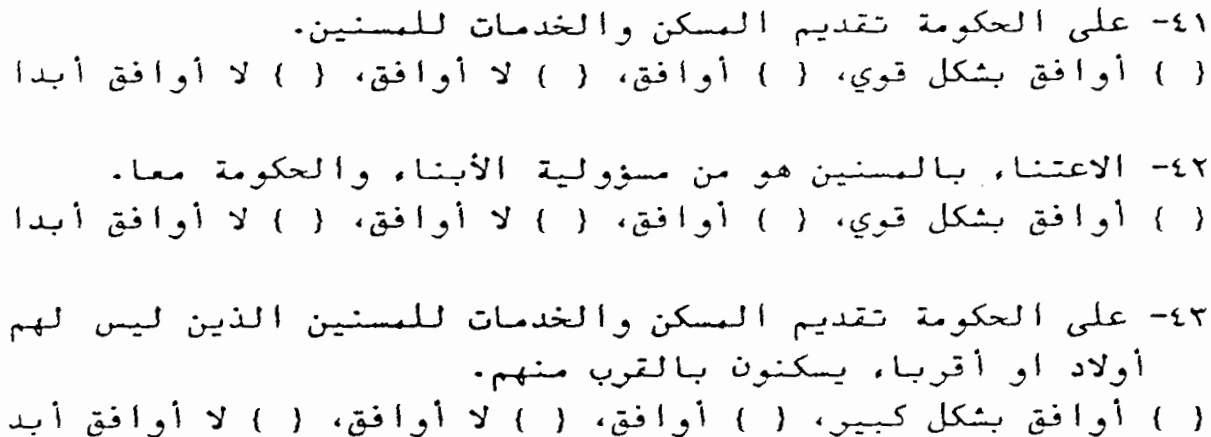

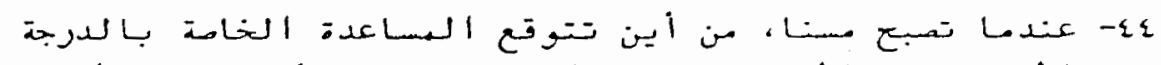

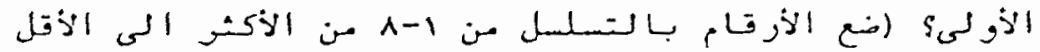

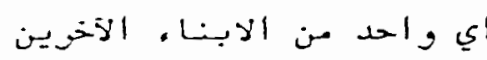
تو تصنا)

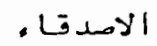

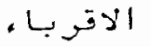

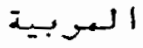

aك)

i)

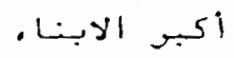

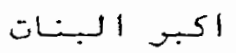

التنسم الفاسم : اعادة: نغلو:

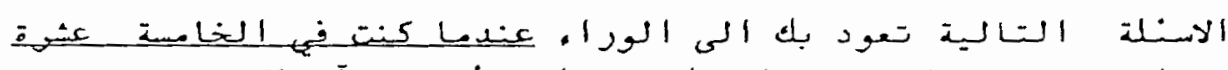

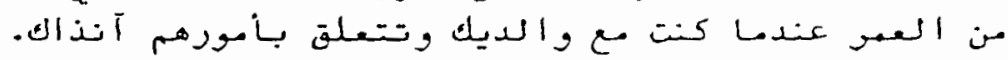

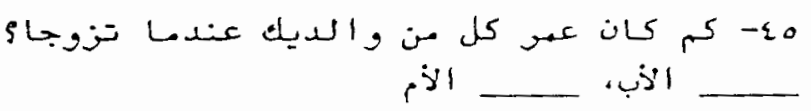

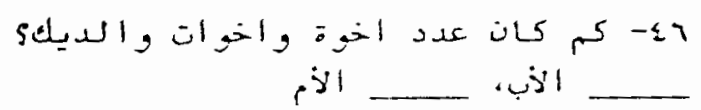

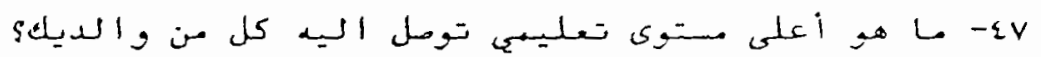
+il الذهـ

$\begin{array}{ll}1 & 1 \\ 1 & 1\end{array}$ 


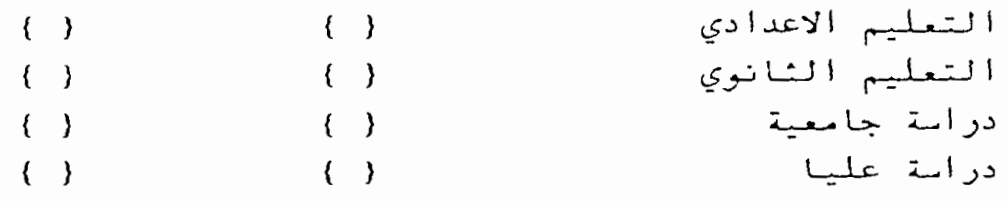

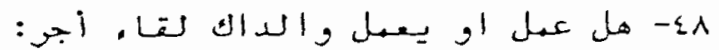

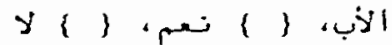

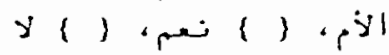

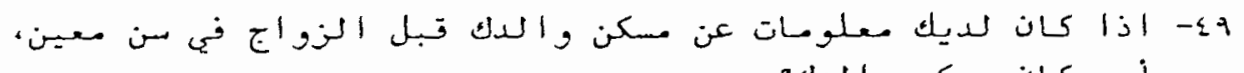

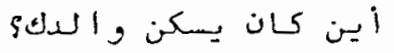

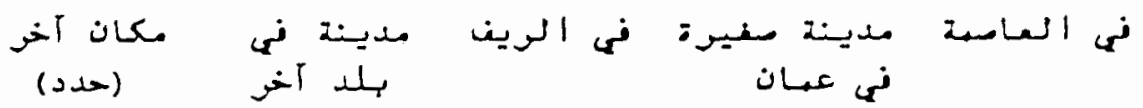

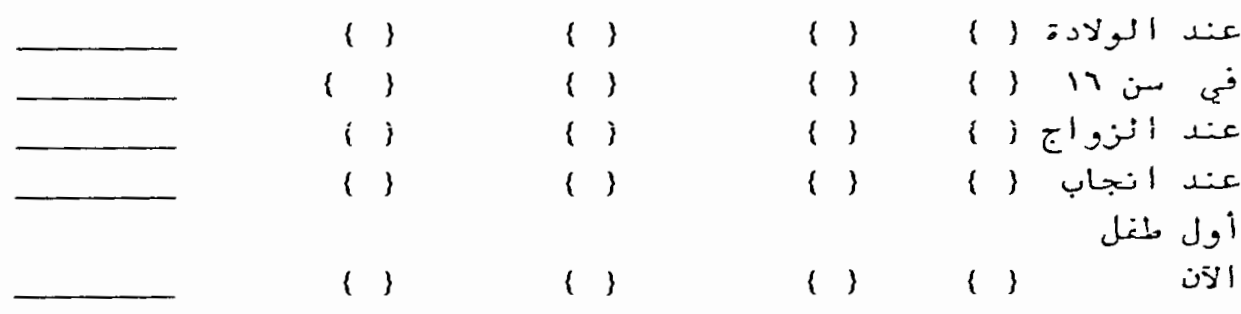




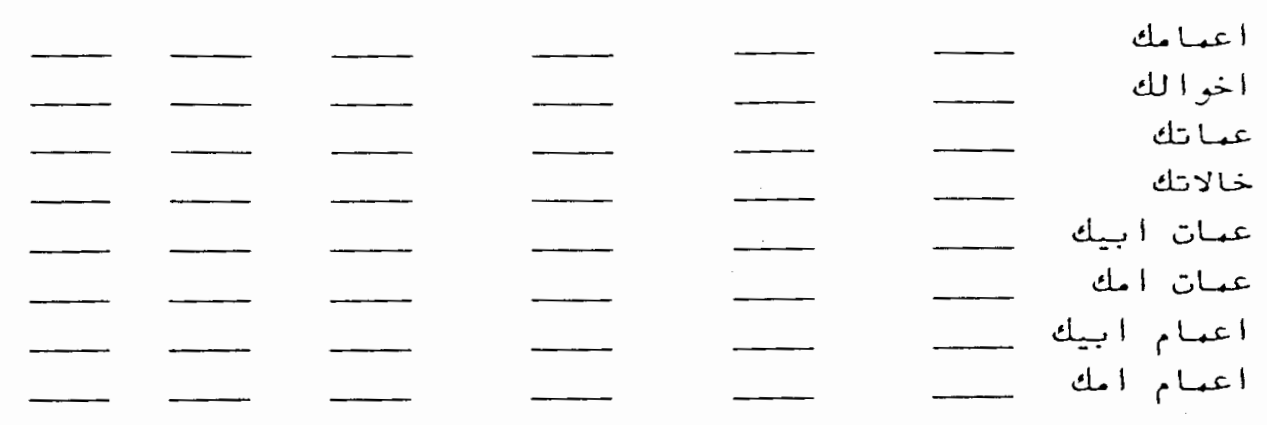

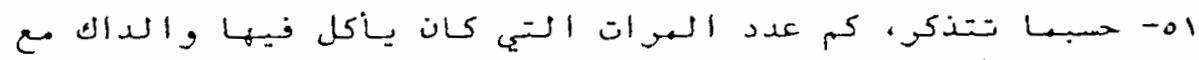

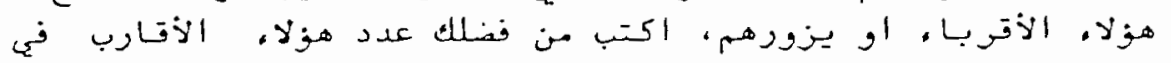
|

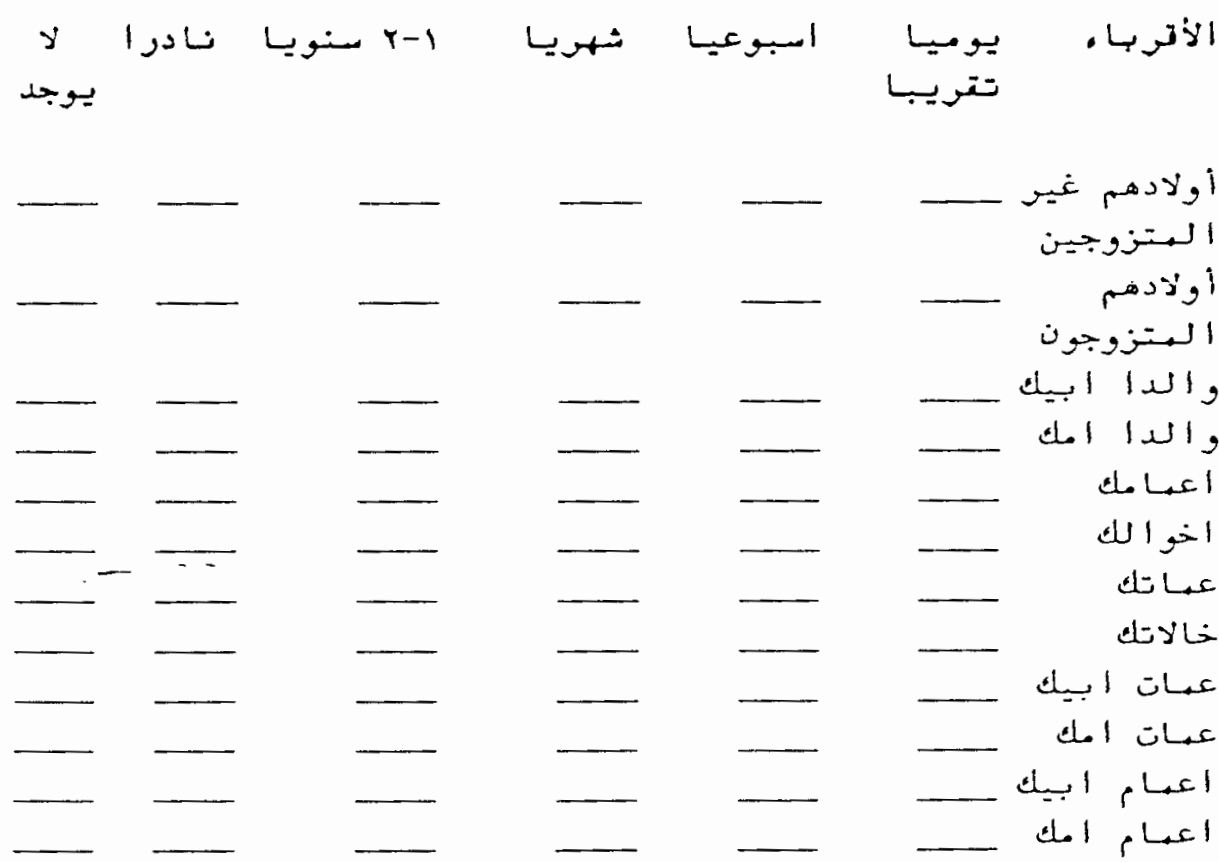

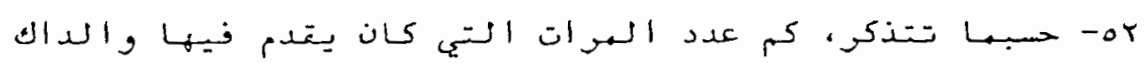

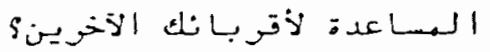

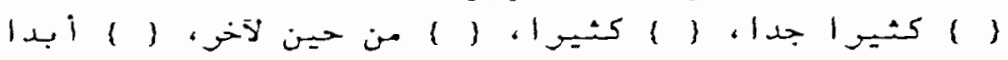

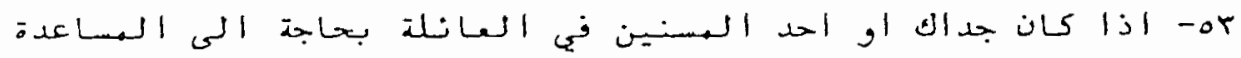




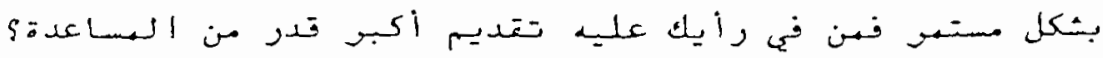

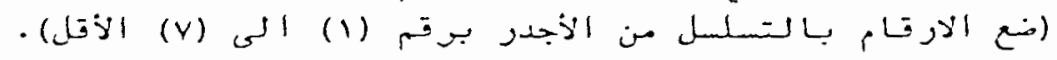

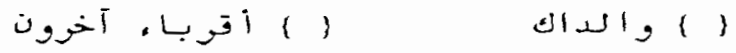

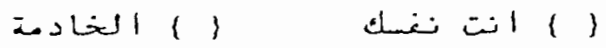

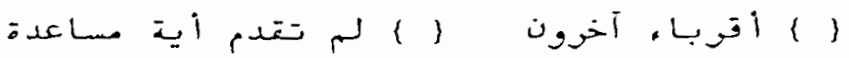

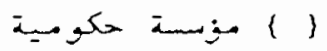

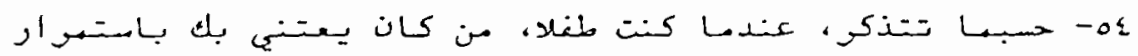

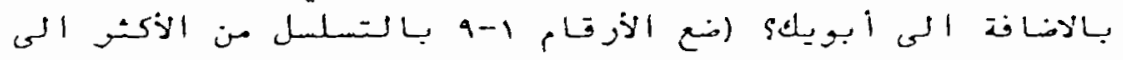

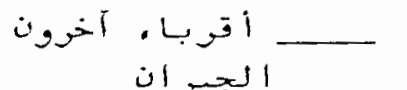

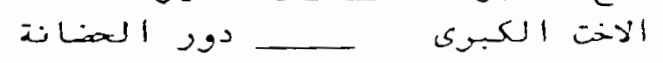

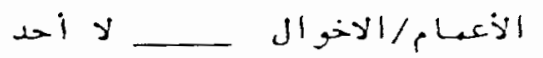

$$
\begin{aligned}
& \text {. }
\end{aligned}
$$

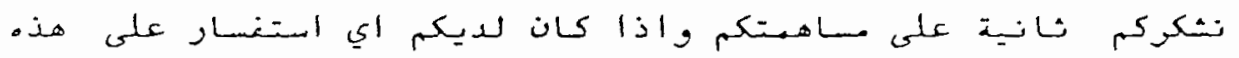

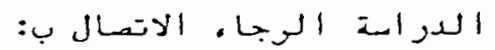

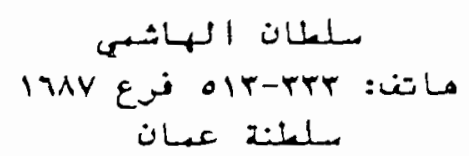

